\title{
Animal Economies and Islamic Conversion in Eastern Ethiopia: Zooarchaeological Analyses from Harlaa, Harar and Ganda Harla
}

\author{
Jane S. Gaastra \\ Institute of Arab and Islamic Studies, University of Exeter, Stocker Road, Exeter, EX4 4ND, UK \\ jane.gaastra@gmail.com \\ Timothy Insoll \\ Institute of Arab and Islamic Studies, University of Exeter, Stocker Road, Exeter, EX4 4ND, UK \\ T.Insoll@Exeter.ac.uk
}

\begin{abstract}
Excavations at three urban sites, Harlaa, Harar, and Ganda Harla, in eastern Ethiopia have recovered substantial assemblages of faunal remains. These, the first to be analysed from Islamic contexts in the country, were studied to reconstruct animal economies, and to assess if it was possible to identify Islamic conversion or the presence of Muslims in archaeological contexts through examining butchery practices and diet via the species present. Differences in animal economies between the sites in, for example, management strategies, use of animals for traction, and presence of imported marine fish, infers the development of different traditions. However, conversion to Islam was evident, and although issues of non-observance, mixed communities, and dietary eclecticism have to be acknowledged, the appearance of a similar range of butchery techniques suggests these were linked with the appearance of Muslim traders, and subsequent spread of Islam.
\end{abstract}

\section{Keywords}

Islam - Ethiopia - zooarchaeology - Harar - Harlaa - butchery religious conversion - diet

\section{Introduction}

Excavations completed as part of the Becoming Muslim project (694254 ERC-2015-Adg) have recovered substantial assemblages of faunal remains from sites in Harlaa (2017-2019), Harar (2014, 2018), and Ganda Harla (2014). These are the first to be published from Islamic sites in Ethiopia, and one of only a few assemblages to have been analysed from sites that are contemporaneous with the better-studied Aksumite (c. 1st-7th centuries AD) and post-Aksumite contexts in the north of Ethiopia and neighboring Eritrea (e.g. Cain 2000; Lesur et al. 2007; Chaix 2013; González-Ruibal et al. 2014; Woldekiros \& D’Andrea 2017). The zooarchaeological analyses were completed with the aim of reconstructing animal economies (herd management strategies, sex proportions of domesticates, body portion distributions, and pathological bone modifications), and assessing if it was possible to identify Islamic conversion or the presence of Muslims in archaeological contexts through examining butchery practices and diet via the species present. Both indicators were useful in recognizing Islam, but non-observance is a factor which has to be acknowledged. Moreover, significant differences were evident between the three sites illustrating variability in animal economies and the development of different traditions over time within eastern Ethiopia.

Answering the questions posed was facilitated by the fact that the faunal material from all three sites demonstrates excellent preservation of both dense and less dense elements. Costal cartilage was recorded in a majority of excavated contexts and foetal, neonatal and infant remains were also recovered from across the sites (Supplementary Tables S1-S28). A reasonably low degree of pre- and postdepositional fragmentation of material was also evident. The systematic dry-sieving of all contexts that was employed allowed the recovery of both small elements and remains of small animals, including birds, fish, and rodents.

\section{The Sites and their Faunal Assemblages}

$$
\text { Harlaa }\left(9^{\circ} 29^{\prime} 10.22 \text { " N, } 41^{\circ} 54^{\prime} 36.96^{\prime \prime} E\right)
$$

The archaeological site of Harlaa is located at $1700 \mathrm{~m}$ ASL on the edge of the main fault escarpment of the southern 


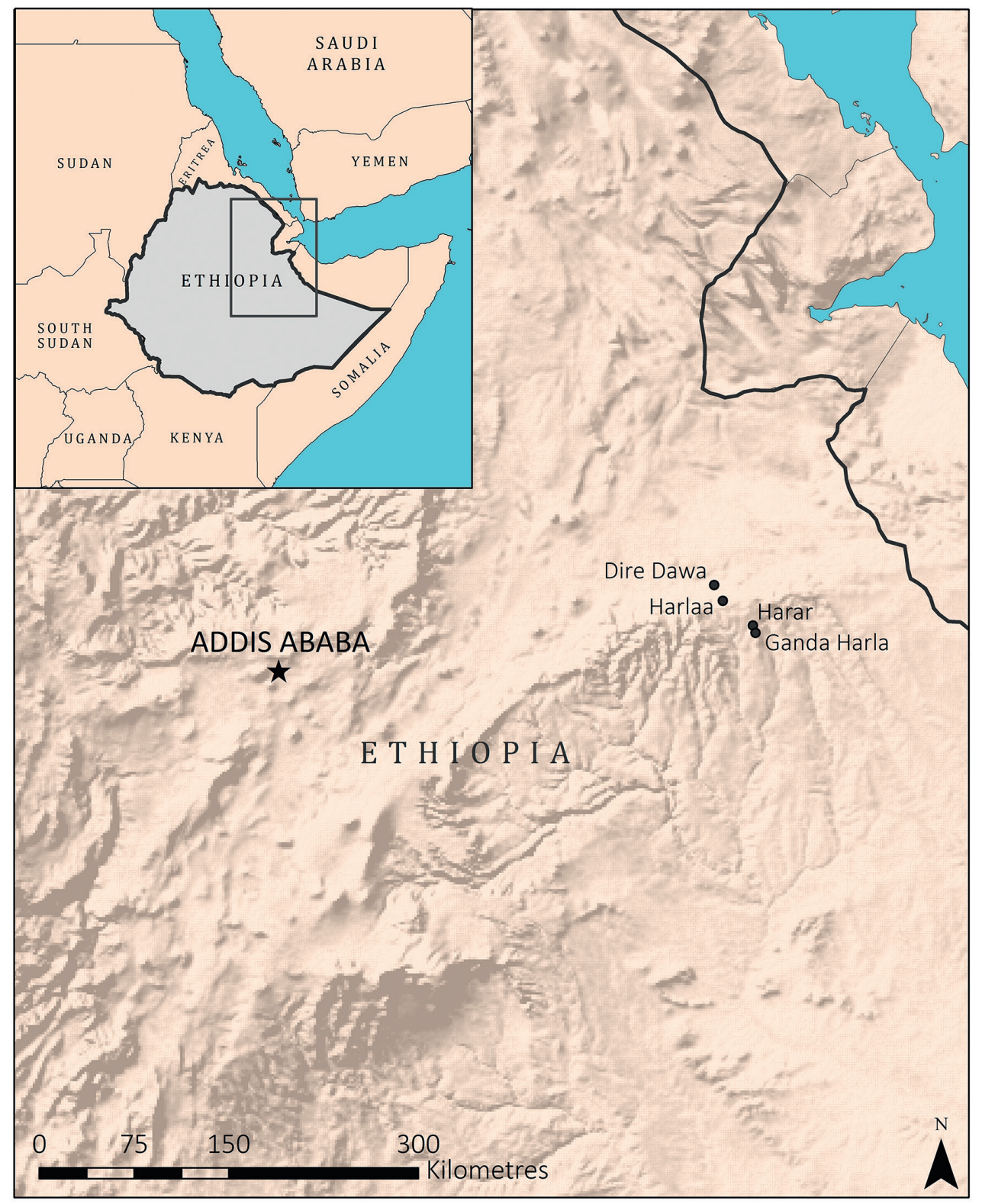

FIGURE 1 The location of the sites in Ethiopia and the Horn of Africa (prepared by N. Khalaf).

Afar margin underneath the modern Oromo village of Ganda Biyo on the Dire Dawa to Dengego road. The accepted name for the archaeological site is Harlaa which is related to the common appellation 'Harla' given to ruined stone-built towns and funerary monuments in the region, whose origins are ascribed by the Oromo to a legendary ancient people of giant status (Chekroun et al. 2011: 79), and who occupied the region before the Oromo arrived (Joussaume \& Joussaume 1972: 22), beginning in the mid16th century (all dates are AD unless otherwise specified). Harlaa is situated approximately $40 \mathrm{~km}$ north-west of Harar and $15 \mathrm{~km}$ southeast of Dire Dawa (Fig. 1). Prior to the start of the current investigation of the site, previous research had consisted of limited survey and surface collections (e.g. Patassini 2006). Harlaa is a large urban centre (Fig. 2) covering a maximum area of approximately $500 \mathrm{~m}$ east to west by $900 \mathrm{~m}$ north to south, excluding outlying cemeteries (Khalaf \& Insoll 2019). It is composed of several elements including a central settlement area, workshops, at least three early mosques, wells, lengths of fortification wall, and cemeteries to the north, east, and west.

Since 2015, excavations have been completed in a mosque (Area A), workshop complex (Area B, except labelled A in 2016), cemeteries (Areas C and D), a house with associated industrial/kitchen facility (Area E), and part of an extensive building complex, which included a defensive wall, and what may have been a reception hall (Area F). Faunal assemblages were recovered from areas B, E, and F. The chronology at Harlaa predates both Harar and Ganda Harlaa. Area B has provided the longest 


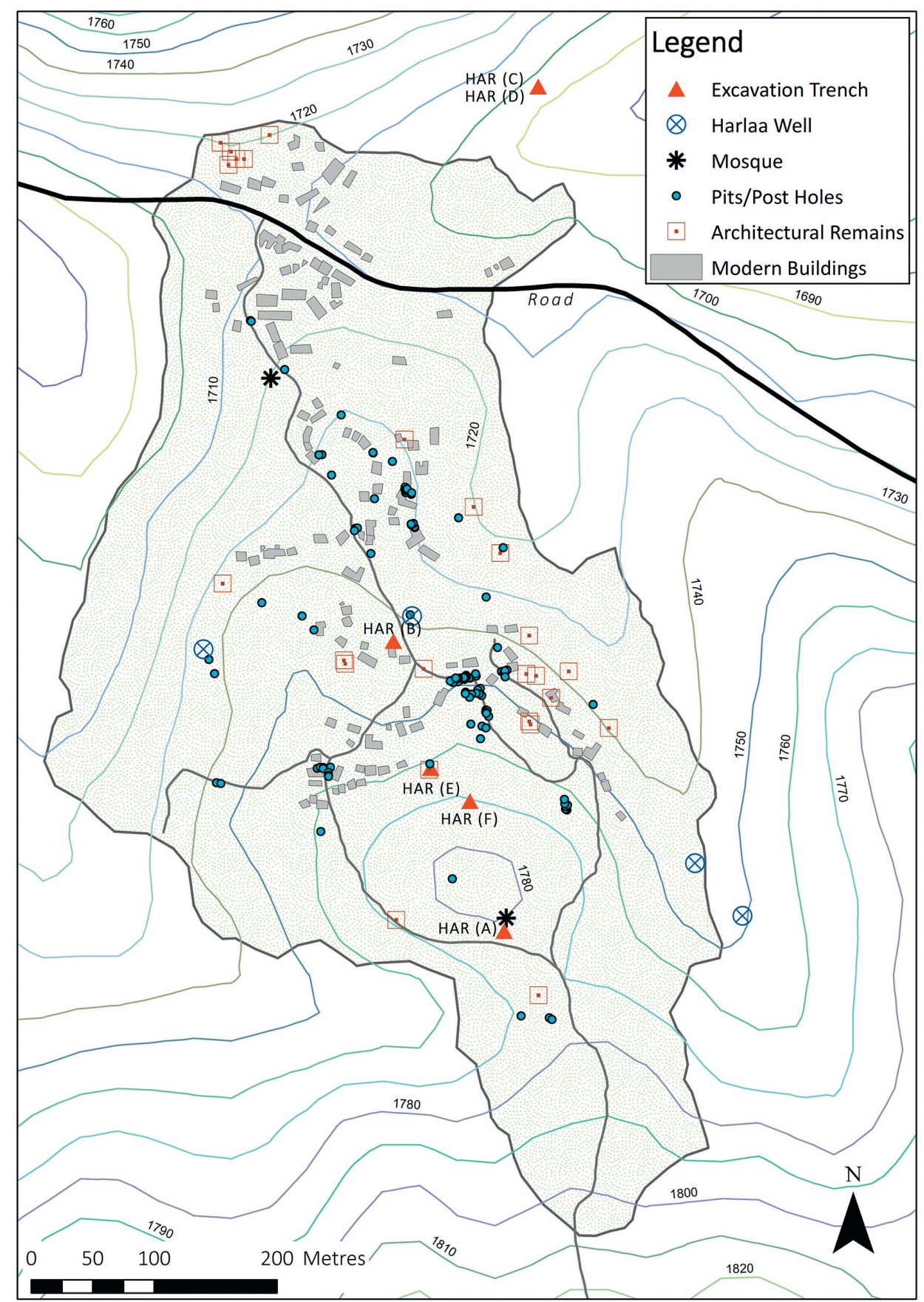

FIGURE 2 The location of the different areas in Harlaa (prepared by N. Khalaf).

chronology with 14 AMS dates obtained spanning the period between the mid-6th and early $15^{\text {th }}$ centuries (Table 1). From these, five phases of occupation and use of the workshop complex can be reconstructed (Table 2). Three AMS dates were obtained from Area $\mathrm{E}$ of between the mid-11th and mid-13th centuries, and two AMs dates from area $\mathrm{F}$ of between the mid-12th and mid-13th centuries (Table 1).

Significant evidence for manufacturing and participation in international Red Sea and western Indian Ocean trade networks, as well as regionally focused ones, has been recovered from Harlaa. Luxury materials, mostly imported, and to a lesser extent manufacturing debris, were distributed across all three areas. Work on provenancing and identifying these materials is ongoing but the most significant concentrations came from the workshop site (Table 3). Imported ceramics included black-onyellow and other glazed wares of Yemeni/southern Red Sea provenance, Iranian lustre glazed frit, and Chinese celadon and white wares. AMS dates from the mosque and one single and one double Muslim burial in the cemeteries attest the presence of a Muslim community at Harlaa by the mid-12th century (Insoll in press) (Table 1). 
TABLE 1 AMS radiocarbon dates from the Harlaa excavations

\begin{tabular}{|c|c|}
\hline Context number & Date and laboratory number \\
\hline HAR 15 (A) 10 & $\begin{array}{l}\text { Cal AD } 1155^{-1255} \text { (2 sigma calibration; } \\
\text { Beta - 419525) }\end{array}$ \\
\hline HAR 15 (B) 6 & $\begin{array}{l}\text { Cal AD } 1155^{-1260} \text { ( } 2 \text { sigma calibration; } \\
\text { Beta - 419526) }\end{array}$ \\
\hline HAR 15 (B) 10 & $\begin{array}{l}\text { Cal AD 1165-1265 (2 sigma calibration; } \\
\text { Beta - 419527) }\end{array}$ \\
\hline HAR $16($ A) 6 & $\begin{array}{l}\text { Cal AD } 1290 \text { to } 1410 \text { ( } 2 \text { sigma calibration; } \\
\left.\text { Beta }-45^{1581}\right)\end{array}$ \\
\hline HAR $16(\mathrm{~A}) 7$ & $\begin{array}{l}\text { Cal AD } 1255 \text { to } 129 \text { o ( } 2 \text { sigma calibration; } \\
\text { Beta }-45^{1582} \text { ) }\end{array}$ \\
\hline HAR $16(\mathrm{~A}) 9$ & $\begin{array}{l}\text { Cal AD } 1190 \text { to } 1275 \text { ( } 2 \text { sigma calibration; } \\
\text { Beta }-45^{1} 5^{8} 3 \text { ) }\end{array}$ \\
\hline $\begin{array}{l}\text { HAR } 17(\text { B) } 6- \\
\text { Hearth }\end{array}$ & $\begin{array}{l}\text { Cal AD } 1220 \text { to } 1285 \text { ( } 2 \text { sigma calibration; } \\
\text { Beta }-461299 \text { ) }\end{array}$ \\
\hline HAR 17 (B) 10 & $\begin{array}{l}\text { Cal AD } 1035 \text { to } 1215 \text { ( } 2 \text { sigma calibration; } \\
\text { Beta }-461300 \text { ) }\end{array}$ \\
\hline HAR 17 (B) 15 & $\begin{array}{l}\text { Cal AD } 535 \text { to } 620 \text { ( } 2 \text { sigma calibration; } \\
\text { Beta }-461301)\end{array}$ \\
\hline $\begin{array}{l}\text { HAR } 17(\text { B) } 24- \\
\text { Hearth }\end{array}$ & $\begin{array}{l}\text { Cal AD } 775 \text { to } 975 \text { ( } 2 \text { sigma calibration; } \\
\text { Beta }-461302 \text { ) }\end{array}$ \\
\hline $\begin{array}{l}\text { HAR } 17(\mathrm{~B}) 24- \\
\text { Under Wall }\end{array}$ & $\begin{array}{l}\text { Cal AD } 1015 \text { to } 1050 \text { and Cal AD } 108 \text { o to } \\
115^{\circ}(2 \text { sigma calibration; Beta }-461303)\end{array}$ \\
\hline HAR 18 (B) 6 & $\begin{array}{l}\text { Cal AD } 1256 \text { to } 1306 \text { ( } 2 \text { sigma calibration; } \\
\text { Beta }-490904 \text { ) }\end{array}$ \\
\hline HAR 18 (B) 13 & $\begin{array}{l}\text { Cal AD } 115^{2} \text { to } 126 \text { o ( } 2 \text { sigma calibration; } \\
\text { Beta }-490905 \text { ) }\end{array}$ \\
\hline HAR 18 (B) 24 & $\begin{array}{l}\text { Cal AD } 776 \text { to } 971 \text { ( } 2 \text { sigma calibration; } \\
\text { Beta }-49 \circ 9 \circ 6)\end{array}$ \\
\hline HAR 18 (B) 26 & $\begin{array}{l}\text { Cal AD } 684 \text { to } 780 \text { (2 sigma calibration; } \\
\text { Beta }-490907)\end{array}$ \\
\hline $\begin{array}{l}\text { HAR } 17(\mathrm{C}) \\
\text { Burial } 1 \text { - Unper }\end{array}$ & $\begin{array}{l}\text { Cal AD } 1330 \text { to } 1340 \text { and Cal AD } 1395 \text { to } \\
1440 \text { ( } 2 \text { sigma calibration; Beta }-461292)\end{array}$ \\
\hline HAR $17(\mathrm{C})$ & Cal AD 1220 to 1285 ( 2 sigma calibration; \\
\hline Burial 2 - Lower & Beta - 461293) \\
\hline HAR $17(\mathrm{D}) 1$ & $\begin{array}{l}\text { Cal AD } 1165 \text { to } 1265 \text { ( } 2 \text { sigma calibration; } \\
\text { Beta }-461294 \text { ) }\end{array}$ \\
\hline HAR $18(\mathrm{E}) 8$ & $\begin{array}{l}\text { Cal AD } 1039 \text { to } 1210 \text { ( } 2 \text { sigma calibration; } \\
\text { Beta }-490908)\end{array}$ \\
\hline HAR $18(\mathrm{E}) 9$ & $\begin{array}{l}\text { Cal AD } 1154 \text { to } 1264 \text { ( } 2 \text { sigma calibration; } \\
\text { Beta - 4909o9) }\end{array}$ \\
\hline HAR 19 (E) 30 & $\begin{array}{l}\text { Cal AD } 1028 \text { to } 1184 \text { ( } 2 \text { sigma calibration; } \\
\text { Beta }-522144 \text { ) }\end{array}$ \\
\hline HAR $19(\mathrm{~F}) 6$ & $\begin{array}{l}\text { Cal AD } 1169 \text { to } 1270 \text { ( } 2 \text { sigma calibration; } \\
\text { Beta }-522142)\end{array}$ \\
\hline HAR $19(F)-($ Cut & Cal AD 1165 to 1265 ( 2 sigma calibration; \\
\hline $\begin{array}{l}\text { Section) Below } \\
\text { Plaster Floor }(2)\end{array}$ & Beta -522143$)$ \\
\hline
\end{tabular}

TABLE 2 The occupation phases in Harlaa, Area B

\section{Phase Date}

\begin{tabular}{ll}
1 & 7 th to 1 oth centuries AD \\
2 & 11 th to mid-13th centuries AD \\
3 & Late 12 th to late $13^{\text {th }}$ centuries AD \\
4 & Mid/late 13 th to early 14 th centuries AD \\
5 & Late 13 th to 14 th centuries AD \\
\hline
\end{tabular}

TABLE 3 Distribution of examples of luxury materials from Harlaa (beads can be both locally made and imported, all other materials listed are imported)

\begin{tabular}{lcllll}
\hline Site & Beads & $\begin{array}{l}\text { Middle } \\
\text { Eastern } \\
\text { glazed } \\
\text { ceramic } \\
\text { sherds }\end{array}$ & $\begin{array}{l}\text { Chinese } \\
\text { ceramic } \\
\text { sherds }\end{array}$ & $\begin{array}{l}\text { Southeast } \\
\text { Asian/ } \\
\text { Chinese }\end{array}$ & $\begin{array}{l}\text { Glass } \\
\text { vessel } \\
\text { fragments }\end{array}$ \\
& & & jartaban & \\
& & & & jar sherds & \\
HAR (B) & 1968 & 114 & 88 & 4 & 353 \\
HAR (E) & 338 & 27 & 13 & 50 & 207 \\
HAR (F) & 151 & 4 & 2 & 0 & 38 \\
\hline
\end{tabular}

The 2017 to 2019 excavations in Area B recovered 33,184 faunal remains totaling $90,422.5 \mathrm{~g}$, of which $8063(24.3 \%$, by weight $63323.8 \mathrm{~g}$ or $70.0 \%$ ) were identifiable. Of these, $2655(32.9 \%$, by weight $38599.1 \mathrm{~g}$ or $61.0 \%)$ were identifiable to genus level. A further $3897(48.3 \%$, by weight $20070.6 \mathrm{~g}$ or $31.7 \%$ ) fragments were identifiable to family level and an additional 1450 ( $17.9 \%$, by weight $4625.0 \mathrm{~g}$ or $7.3 \%$ ) identifiable only to element. The 2018 and 2019 excavations of Area E recovered 13,155 faunal remains totaling 23060.6 g. Of these, 612 were identifiable to genus level (4.6\%, by weight $7369.4 \mathrm{~g}$ or $31.9 \%$ ), 1079 identifiable to family level (8.2\%, by weight $4956.6 \mathrm{~g}$ or $21.5 \%)$ and 399 (3.0\%, by weight $895.5 \mathrm{~g}$ or $3.9 \%$ ) to element and animal size class. The 2019 excavations in Area F recovered 1847 fragments totaling 2533.0 g. From this sample 93 fragments were identifiable to genus level $(5.0 \%$, by weight $952.7 \mathrm{~g}$ or $37.6 \%), 125$ (6.8\%, by weight $425.4 \mathrm{~g}$ or $16.8 \%)$ were identifiable to family level and $49(2.6 \%$, by weight $74.8 \mathrm{~g}$ or $3.0 \%$ ) were identifiable only to element and animal size class.

Unidentifiable material from these excavations included small fragments of cranium or long bone shaft which could not be further identified to element. In comparison to the identifiable elements, the 25,121 unidentifiable fragments from Area B averaged $1.08 \mathrm{~g}$ (compared with 


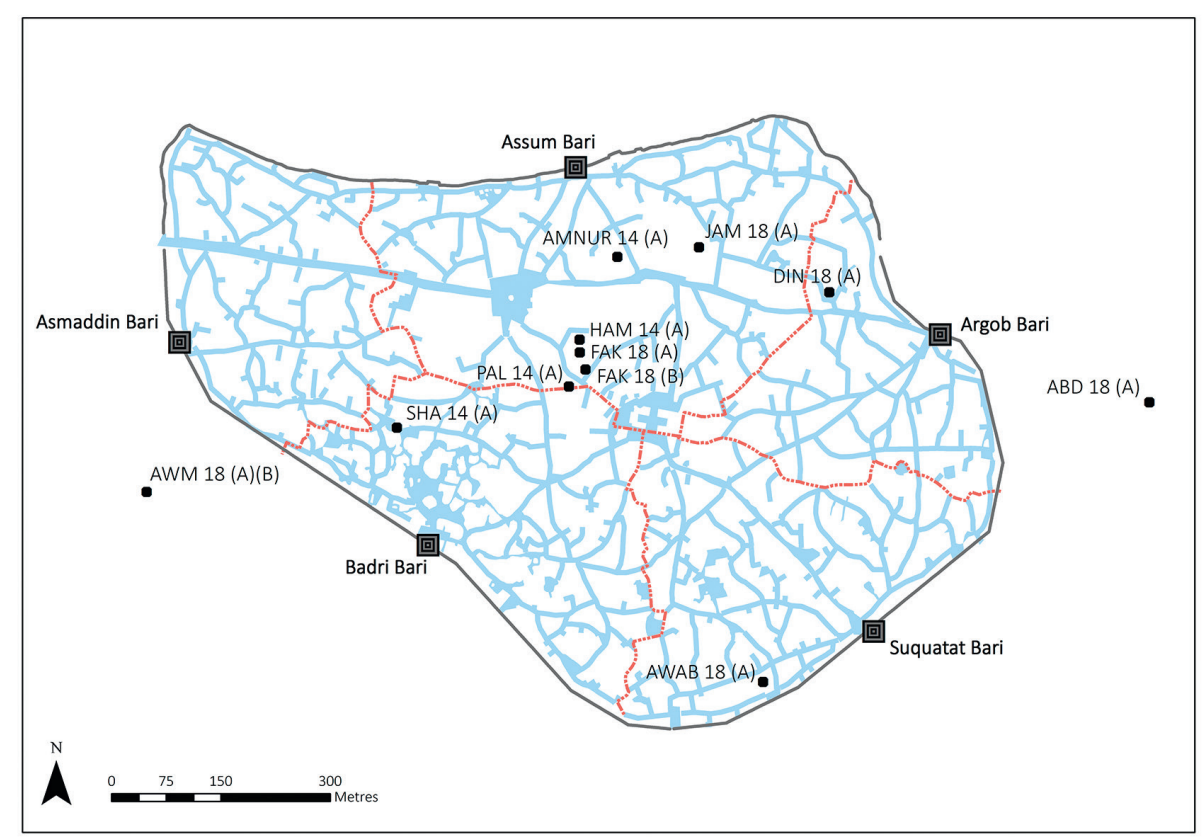

FIGURE 3 The location of the excavations in Harar (prepared by N. Khalaf).

$7.85 \mathrm{~g}$ for identifiable material), the 11,037 unidentifiable fragments from Area E averaged o.89 $\mathrm{g}$ (compared with $6.34 \mathrm{~g}$ for identifiable fragments) and the 1580 unidentifiable fragments from Area $\mathrm{F}$ averaged o.68g (compared with $5.44 \mathrm{~g}$ for identifiable remains). In the majority, these comprised fragments of appendicular cortical bone (shaft fragments), although the remainder of the skeleton (fragments from the cranium and axial portions) were also well represented. Discussions of fragments identifiable to the level of element, family and genus are hereafter discussed in NISP (Number of Identified Specimens) unless otherwise stated. Further detail as to the distribution of unidentifiable fragments by fragment type and animal size class is available in the Supplementary Table S1.

\section{Harar $\left(9^{\circ} 18^{\prime} 33.21^{\prime \prime} \mathrm{N}, 4^{\circ}{ }^{\circ} 8^{\prime} 15.84^{\prime \prime} E\right)$}

Harar is also situated in the Somali Plateau, at $1900 \mathrm{~m}$ ASL, but in a more heavily vegetated landscape (Khalaf \& Insoll 2019). At the core of Harar is a historic city, surrounded by a wall, the djugel. This is built of locally quarried calcareous tuff (Hashi stone) mortared with mud and wooden reinforcements (Ahmed 1990: 321). It encompasses an area of c. $1000 \times 800 \mathrm{~m}$ and is accessed by five gates, with corresponding quarters (Horton 1994: 195). The walled city contains within it approximately 2000 houses, 82 mosques, and numerous saints' tombs and shrines (CIRPS \& Harari People National Regional State 2003), the result of important urban development over many centuries (Insoll 2017).

Excavations at nine locations in and immediately adjacent to the walled city (five mosques, one shrine, two settlement areas, one blacksmithing location) (Fig. 3), have provided eight AMS radiocarbon dates of between the $15^{\text {th }}$ and 19th/early 2oth centuries (cf. Insoll 2017; Insoll and Zekaria 2019). The excavations indicate that occupation in Harar post-dates the late $15^{\text {th }}$ century, and until evidence to the contrary is found, it is suggested that the city and its mosques date from this era and were linked with the establishment of Harar as the capital of the Sultanate of Adal (c. 1415 to 1577) (Insoll 2017; Insoll and Zekaria 2019). Prior to this the Harari, likely in the form of the 'Harla', were elsewhere, possibly at Harlaa or one or more of the largely uninvestigated abandoned stone town sites, such as Ganda Harla, that are found across the eastern Harar Plateau and the Chercher Mountains (cf. Insoll 2017: 209210). Although Harar functioned as a trade centre that connected the eastern Ethiopian highlands, arid lowlands, and the Gulf of Aden, the situation was very different to Harlaa as few luxury materials have been recovered. These comprise four glazed ceramic sherds of probable Middle Eastern Origin, one sherd of Chinese blue and white ware of 18th or 19th century date and a single fragment from a green glass bottle or flask neck (Insoll 2017: 207; Insoll and Zekaria 2019).

For the purposes of this discussion, the faunal remains from all the units in Harar are combined rather than presented as separate assemblages. This does not bias the analysis as there were no meaningful disparities in the quantities found or species present. The excavations at Harar recovered 887 bone fragments totaling 4974.8g. Of these, $173(19.5 \%$, by weight $1859.3 \mathrm{~g}$ or $37.4 \%)$ were identifiable to genus level, $142(16.0 \%$, by weight $1326.4 \mathrm{~g}$ or 
$26.7 \%)$ were identifiable to family level, and 6 o $(6.8 \%$, by weight $472.4 \mathrm{~g}$ or $9.5 \%$ ) only to element and animal body size class.

\section{Ganda Harla $\left(9^{\circ} 25^{\prime} 81 \cdot 5^{\prime \prime} \mathrm{N}, 4^{\circ}{ }^{\circ} 4^{\prime} 35 \cdot 3^{\prime \prime} E\right)$}

This abandoned settlement is located $12.5 \mathrm{~km}$ southeast of Harar on a hill west of the village of Sofi. It is also linked with the Harla in local tradition (Tesfaye et al. 2013: 3). Numerous structures and enclosures built of dry stone were recorded on the upper part of the site and delimited to their north by a large defensive wall, also built of dry stone, running down the hill. A test excavation of 120 $\times 220 \mathrm{~cm}$ was completed inside one of these buildings which provided a radiocarbon date of cal AD 1466 to 1645 (2 sigma calibration; GX-33811). The function of the building, whether military, civic, storeroom, or residential, was unclear, but fragments of plaster and worked masonry suggested it had been of some importance (Insoll et al. 2014: 103-104). Unfortunately, the security situation has precluded further work, but based on the $\mathrm{C}_{1} 4$ date it is suggested that Ganda Harla was founded at or just prior to the establishment of Harar as part of an expansion of settlement accompanying increased Islamisation.

The excavations at Ganda Harla recovered 141 fragments totaling $2191.3 \mathrm{~g}$. Of these, $61(43.4 \%$, by weight $1269.1 \mathrm{~g}$ or $57.9 \%$ ) were identifiable to genus level, 43 (30.5\%, by weight $720.4 \mathrm{~g}$ or $32.9 \%$ ) were identifiable to the level of family and 2 (1.4\%, by weight $39.6 \mathrm{~g}$ or $1.8 \%)$ identifiable only to element and animal body size class. As at Harar, unidentifiable fragments comprised predominately small fragments of cortical bone but represented fragments from across the animal skeleton. These were also somewhat larger compared with those from Harlaa, averaging $2.4 \mathrm{~g} / 5.8 \mathrm{~g}$ compared with $9.7 \mathrm{~g} / 18.7 \mathrm{~g}$ for identifiable material from Harar and Ganda Harla.

\section{Taxonomic Distributions}

Identified faunal remains were categorised according to genus and species, where possible. Where specific taxonomic identification was not possible, elements were classified according to the most precise possible broader taxonomic category, such as small bovid, bird (aves), small carnivore, or medium mammal. Taxonomic identifications were made using Boessneck et al. (1963), Olsen (1960), Walker (1986), Zeder \& Lapham (2010), and Zeder \& Pilaar (2010) as well as a digital reference collection. Each element was identified either to taxon or taxonomic category with further information recorded as to element side, percentage of completeness, age or sex information where present, breakage patterns, burning, weathering, gnawing, butchery evidence (such as cutmarks), and other taphonomic information. Identified elements are given here as NISP (Number of Identified Specimens). Comparisons of the representation of elements for the most common mammals in each faunal sample indicates no significant differences in the representation of bodily portions either through time or between the sites (see Supplementary Table S1). In all cases, the distribution of elements suggests the presence of animals as complete carcasses.

The majority of fauna from all three sites come from domestic taxa (Table 4). For those remains which could be identified to genus level, domesticates represent between $59-100 \%$ of NISP with the majority of samples containing c. $60-77 \%$ domestic fauna (Table 5). At Harlaa, the most common domesticate is the goat (Capra hircus) at c. 35$40 \%$ whereas at Harar and Ganda Harla it is cattle (Bos taurus/indicus) at $45-64 \%$ (Tables 4 and 5). The sole exception is the very small sample from Phase 1 of Area B at Harlaa, where the camel is the most common domesticate $(26.3 \%)$. The second most common domesticate is either cattle (Harlaa) or goat (Harar and Ganda Harla). Sheep at Harlaa (excepting the small sample from Phase 1) are the third most common domesticate followed by transport animals. This situation is reversed at Harar and Ganda Harlaa where transport livestock (camel, donkey and horse) combined are more common than either sheep or goats (Tables 5 and 6 ). The representation of transport animals in different areas of Harlaa is uneven, with an overall decline in Area B through time and a greatly reduced representation in Areas E and F (6.3\% and 7.5\%) compared with the contemporaneous Phase 2 sample from Area B (14.9\%). Transport animals across all contexts are dominated by equids (donkey and horse), with the decrease in transport animals in Area B largely due to the decreasing presence of camels in later phases (Table 6).

Remains of domestic chicken (Gallus gallus domesticus) were recovered from Harlaa and Harar but are absent from Ganda Harla (as are all bird bones). These are systematically present across all contexts at Harlaa except the small sample from phase 1 , Area B, and their representation is fairly consistent at c. $3-7 \%$ at Harlaa and $2.3 \%$ at Harar. Males appear to be infrequent as adults but are represented as subadult individuals, suggesting that extraneous roosters were culled prior to adulthood. Domestic guinea fowl (Numida meleagris) is present only at Harlaa, and is seen only in Areas E and F and phases 2 and 3 of Area B. It appears that guinea fowl were not kept in later periods.

The divergence in consumption of small vs. large domestic bovids between Harlaa and Harar/Ganda Harla 
TABLE 4 Identified fauna from Harlaa, Harar and Ganda Harla. Animal size classes follow Brain (1974) with small mammals (including small canid, small carnivore and small primate) equivalent to animal size class 1 (o-23 kg), small wild bovid, small bovid and medium mammal equivalent to animal size class $2\left(23^{-}-84 \mathrm{~kg}\right)$ and large wild bovid, large bovid and large mammal equivalent to animal size class 3 (84-296 kg). No remains were recovered from animal size classes 4 (296-90o kg) or 5 (over 9oo kg)

\begin{tabular}{|c|c|c|c|c|c|c|c|c|c|c|c|c|c|c|c|c|c|c|}
\hline \multirow[b]{3}{*}{ Taxon } & \multicolumn{10}{|c|}{ Harlaa B } & \multicolumn{2}{|c|}{ Harlaa E } & \multicolumn{2}{|c|}{ Harlaa F } & \multicolumn{2}{|c|}{ Harar } & \multicolumn{2}{|c|}{ Ganda Harla } \\
\hline & \multicolumn{2}{|c|}{ Phase 1} & \multicolumn{2}{|c|}{ Phase 2} & \multicolumn{2}{|c|}{ Phase 3} & \multicolumn{2}{|c|}{ Phase 4} & \multicolumn{2}{|c|}{ Phase 5} & \multirow[b]{2}{*}{ NISP } & \multirow[b]{2}{*}{$\%$} & \multirow[b]{2}{*}{ NISP } & \multirow[b]{2}{*}{$\%$} & \multirow[b]{2}{*}{ NISP } & \multirow[b]{2}{*}{ P \% } & & \\
\hline & NISP & $\%$ & NISP & $\%$ & NISP & $\%$ & NISP & $\%$ & NISP & $\%$ & & & & & & & NISP & $\%$ \\
\hline $\begin{array}{l}\text { Bos taurus/ } \\
\text { indicus }\end{array}$ & 3 & $6.3 \%$ & 205 & $17 \cdot 7 \%$ & 9 & $12.0 \%$ & 36 & $13.8 \%$ & 100 & $20.4 \%$ & 140 & $18.8 \%$ & 23 & $21.3 \%$ & 40 & $30.3 \%$ & 23 & $37 \cdot 7 \%$ \\
\hline Ovis aries & 2 & $4.2 \%$ & 121 & $10.5 \%$ & 10 & $13 \cdot 3 \%$ & 33 & $12.6 \%$ & 68 & $13.9 \%$ & 82 & $11.0 \%$ & 11 & $10.2 \%$ & 8 & $6.1 \%$ & 1 & $1.6 \%$ \\
\hline Capra hircus & 3 & $6.3 \%$ & 346 & $29.9 \%$ & 18 & $24.0 \%$ & 92 & $35.2 \%$ & 141 & $28.8 \%$ & 174 & $23.4 \%$ & 31 & $28.7 \%$ & 16 & $12.1 \%$ & 7 & $11.5 \%$ \\
\hline Camellus & 5 & $10.4 \%$ & $6 o$ & $5.2 \%$ & 1 & $1.3 \%$ & 7 & $2.7 \%$ & 4 & o.8\% & - & & - & & 3 & $2.3 \%$ & - & \\
\hline Equus asinus & 3 & $6.3 \%$ & 19 & $1.6 \%$ & 1 & $1.3 \%$ & 8 & $3.1 \%$ & 9 & $1.8 \%$ & 15 & $2.0 \%$ & 1 & $0.9 \%$ & 7 & $5.3 \%$ & 2 & $3 \cdot 3 \%$ \\
\hline Equus caballus & 2 & $4.2 \%$ & 24 & $2.1 \%$ & - & & 3 & $1.1 \%$ & 8 & $1.6 \%$ & 6 & $0.8 \%$ & 2 & $1.9 \%$ & 6 & $4.5 \%$ & 3 & $4.9 \%$ \\
\hline Equus sp. & 1 & $2.1 \%$ & 23 & $2.0 \%$ & 2 & $2.7 \%$ & 10 & $3.8 \%$ & 19 & $3.9 \%$ & 11 & $1.5 \%$ & 3 & $2.8 \%$ & 4 & $3.0 \%$ & - & \\
\hline Canis familiaris & - & - & 3 & $0.3 \%$ & 1 & $1.3 \%$ & 1 & $0.4 \%$ & - & & 3 & $0.4 \%$ & 1 & $0.9 \%$ & - & & - & \\
\hline Felis catus & - & - & 3 & $0.3 \%$ & - & & 1 & $0.4 \%$ & 3 & o.6\% & 4 & $0.5 \%$ & - & & 1 & $0.8 \%$ & - & \\
\hline Kobus sp. & - & - & 3 & $0.3 \%$ & - & & 1 & $0.4 \%$ & 1 & $0.2 \%$ & 5 & $0.7 \%$ & 2 & $1.9 \%$ & 2 & $1.5 \%$ & 1 & $1.6 \%$ \\
\hline Oryx sp. & - & - & 8 & $0.4 \%$ & 1 & & 2 & & 5 & $0.2 \%$ & 2 & $0.3 \%$ & 2 & $1.9 \%$ & 6 & $4.5 \%$ & 2 & $3.3 \%$ \\
\hline Tragelaphus sp. & - & - & 9 & o.8\% & 1 & $1.3 \%$ & 2 & $0.8 \%$ & 5 & $1.2 \%$ & 18 & $2.4 \%$ & 1 & $0.9 \%$ & 5 & $3.8 \%$ & 7 & $10.4 \%$ \\
\hline $\begin{array}{l}\text { large wild } \\
\text { bovid }\end{array}$ & - & - & 16 & $1.4 \%$ & 4 & $5 \cdot 3 \%$ & 4 & $1.5 \%$ & 13 & $2.7 \%$ & - & & - & & 2 & $1.5 \%$ & - & \\
\hline Litocranius sp. & - & - & 5 & $0.4 \%$ & - & & 4 & $1.5 \%$ & 2 & $0.4 \%$ & - & & - & & 1 & $0.8 \%$ & - & \\
\hline Reduncasp. & - & - & 21 & $1.8 \%$ & 3 & $4.0 \%$ & 2 & o.8\% & 7 & $1.4 \%$ & 13 & $1.7 \%$ & 1 & $0.9 \%$ & 2 & $1.5 \%$ & - & \\
\hline Nanger sp. & - & - & 17 & $1.5 \%$ & 2 & $2.7 \%$ & 5 & $1.9 \%$ & 3 & o.6\% & 7 & $0.9 \%$ & 1 & $0.9 \%$ & - & & - & \\
\hline Sylvicapra sp. & - & - & - & . & 1 & $1.3 \%$ & - & & - & & - & & - & & - & & - & \\
\hline Dorcatragus sp. & - & - & 23 & $2.0 \%$ & 1 & $1.3 \%$ & 5 & $1.9 \%$ & 11 & $2.2 \%$ & 9 & $1.2 \%$ & 1 & $0.9 \%$ & 1 & $0.8 \%$ & - & \\
\hline Gazella sp. & - & - & 10 & $0.9 \%$ & 1 & $1.3 \%$ & 2 & о. $8 \%$ & 3 & о.6\% & 2 & $0.3 \%$ & - & & 2 & $1.5 \%$ & 1 & $1.6 \%$ \\
\hline Ourebi sp. & - & - & 3 & $0.3 \%$ & - & & 1 & $0.4 \%$ & 2 & $0.4 \%$ & 2 & $0.3 \%$ & 1 & $0.9 \%$ & 2 & $1.5 \%$ & 1 & $1.6 \%$ \\
\hline Madoqua sp. & - & - & 2 & $0.2 \%$ & - & & - & & 3 & o.6\% & 2 & $0.3 \%$ & 3 & $2.8 \%$ & - & & - & \\
\hline Oreotragus sp. & - & - & 1 & $0.1 \%$ & - & & - & & - & & - & & - & & - & & - & \\
\hline $\begin{array}{l}\text { small wild } \\
\text { bovid }\end{array}$ & - & - & 43 & $3 \cdot 7 \%$ & 8 & $10.7 \%$ & 9 & $3 \cdot 4 \%$ & 12 & $2.4 \%$ & 38 & $5.1 \%$ & 3 & $2.8 \%$ & 3 & $2.3 \%$ & - & \\
\hline $\begin{array}{l}\text { Potamochoerus } \\
\text { sp. }\end{array}$ & - & - & 3 & $0.3 \%$ & - & & - & & 1 & $0.2 \%$ & 1 & $0.1 \%$ & - & & - & & 1 & $1.6 \%$ \\
\hline $\begin{array}{l}\text { Phacochoerus } \\
\text { sp. }\end{array}$ & - & - & 2 & $0.2 \%$ & - & & 1 & $0.4 \%$ & - & & - & & - & & - & & - & \\
\hline Suid indet. & - & - & 3 & $0.3 \%$ & - & & 1 & $0.4 \%$ & - & & 3 & $0.4 \%$ & - & & - & & 1 & $1.6 \%$ \\
\hline Orycteropus sp. & - & - & 3 & $0.3 \%$ & - & & - & & - & & - & & - & & - & & - & \\
\hline Histrix sp. & - & - & - & - & - & & 1 & $0.4 \%$ & - & & - & & - & & - & & - & \\
\hline Lepus sp. & - & - & 1 & $0.1 \%$ & - & & 1 & $0.4 \%$ & - & & - & & - & & - & & - & \\
\hline Genetta sp. & - & - & 1 & $0.1 \%$ & - & & - & & - & & 1 & $0.1 \%$ & - & & - & & - & \\
\hline Mungos sp. & - & - & - & - & - & & - & & - & & 1 & $0.1 \%$ & - & & - & & - & \\
\hline Pantera pardus & - & - & - & - & - & & - & & - & & - & & - & & 2 & $1.5 \%$ & - & \\
\hline small canid & - & - & 2 & $0.2 \%$ & - & & - & & 1 & $0.2 \%$ & 1 & $0.1 \%$ & - & & - & & - & \\
\hline small carnivore & - & - & 14 & $1.2 \%$ & 1 & $1.3 \%$ & 6 & $2.3 \%$ & 4 & $0.8 \%$ & 10 & $1.3 \%$ & - & & 1 & $0.8 \%$ & - & \\
\hline small primate & - & - & 1 & $0.1 \%$ & - & & - & & - & & - & & - & & - & & - & \\
\hline small bovid & 17 & & 1090 & & 60 & & 290 & & 442 & & 734 & & 81 & & 43 & & 9 & \\
\hline large bovid & 9 & & 311 & & 15 & & 57 & & 153 & & 293 & & 36 & & 99 & & 34 & \\
\hline small mammal & - & - & 8 & & - & - & 1 & & 1 & & 6 & & - & - & - & - & - & - \\
\hline $\begin{array}{l}\text { medium } \\
\text { mammal }\end{array}$ & 1 & & 286 & & 11 & & 68 & & 125 & & 189 & & 28 & & 6 & & 2 & \\
\hline large mammal & 2 & & 159 & & 8 & & 27 & & 74 & & 92 & & 11 & & 49 & & & \\
\hline Pisces indet. & - & - & 4 & $0.3 \%$ & - & - & 3 & $0.4 \%$ & - & - & 8 & & - & - & - & - & - & - \\
\hline Mugilidae & - & - & 19 & $1.6 \%$ & 2 & $1.1 \%$ & 10 & $1.4 \%$ & 5 & $0.04 \%$ & 3 & & 1 & & - & - & - & - \\
\hline Scombridae & - & - & 2 & $0.2 \%$ & 3 & $1.7 \%$ & - & - & 1 & $0.01 \%$ & 2 & & 2 & & - & - & - & - \\
\hline
\end{tabular}


TABLE 4 Identified fauna from Harlaa, Harar and Ganda Harla (cont.)

\begin{tabular}{|c|c|c|c|c|c|c|c|c|c|c|c|c|c|c|c|c|c|c|}
\hline \multirow[b]{3}{*}{ Taxon } & \multicolumn{10}{|c|}{ Harlaa B } & \multicolumn{2}{|c|}{ Harlaa E } & \multicolumn{2}{|c|}{ Harlaa F } & \multicolumn{2}{|c|}{ Harar } & \multicolumn{2}{|c|}{ Ganda Harla } \\
\hline & Phase & & Phase & & Phase & & Phase & e 4 & Phase & & & & & & & & & \\
\hline & NISP & $\%$ & NISP & $\%$ & NISP & $\%$ & NISP & $\%$ & NISP & $\%$ & NISP & $\%$ & NISP & $\%$ & NISP & $\%$ & NISP & $\%$ \\
\hline Pleuronectiform & - & - & - & - & - & - & 1 & $0.1 \%$ & - & - & - & - & - & - & - & - & - & - \\
\hline Aves indet. & - & - & 86 & $7 \cdot 4 \%$ & 11 & $2.7 \%$ & 43 & $5 \cdot 4 \%$ & 47 & $7 \cdot 3 \%$ & 103 & $13.8 \%$ & 10 & $9 \cdot 3 \%$ & 5 & $3.8 \%$ & - & - \\
\hline Anatidae & - & - & 2 & $0.2 \%$ & - & - & - & - & - & - & 1 & $0.1 \%$ & - & - & - & - & - & - \\
\hline Columbidae & - & - & - & - & - & - & 1 & $0.4 \%$ & - & - & 1 & $0.1 \%$ & 1 & $0.9 \%$ & - & - & - & - \\
\hline Gallform & - & - & 8 & $0.7 \%$ & 3 & $0.4 \%$ & - & - & 3 & o.6\% & 10 & $1.3 \%$ & 2 & $1.9 \%$ & - & - & - & - \\
\hline Anseriform & - & - & - & - & - & - & - & - & 1 & $0.2 \%$ & 2 & $0.3 \%$ & - & - & - & - & - & - \\
\hline Passerine & - & - & - & - & - & - & - & - & - & - & - & - & 1 & $0.9 \%$ & - & - & - & - \\
\hline $\begin{array}{l}\text { Gallus gallus } \\
\text { domesticus }\end{array}$ & - & - & 39 & $3 \cdot 4 \%$ & 20 & $4.0 \%$ & 68 & $3.1 \%$ & 43 & $4.5 \%$ & $5^{1}$ & $6.8 \%$ & 5 & $4.6 \%$ & 3 & $2.3 \%$ & - & - \\
\hline $\begin{array}{l}\text { Numida } \\
\text { meleagris }\end{array}$ & - & - & 4 & $0.3 \%$ & 1 & $1.3 \%$ & - & - & - & - & 14 & $1.9 \%$ & 1 & $0.9 \%$ & - & - & - & - \\
\hline $\begin{array}{l}\text { Eggshell (c.f. } \\
\text { Struthionidae) }\end{array}$ & - & - & 2 & & - & - & - & - & - & - & 3 & & 1 & & 1 & & - & - \\
\hline Rodentia & - & - & 3 & & - & - & 14 & & 23 & & 22 & & 5 & & 1 & & - & - \\
\hline Testudine & - & - & 1 & $0.1 \%$ & - & - & - & - & - & - & - & - & - & - & 1 & $0.8 \%$ & - & - \\
\hline Stigmochelys & - & - & - & - & - & - & - & - & - & - & - & - & - & - & 9 & $6.8 \%$ & 11 & $18 \%$ \\
\hline Total & 48 & & 3014 & & 172 & & 727 & & 1307 & & 2084 & & 270 & & 330 & & 106 & \\
\hline
\end{tabular}

TABLE 5 Proportional representation of domestic taxa from Harlaa, Harar and Ganda Harla. Given here are both the counts (N) and percentage (\%) of NISP for each domesticate

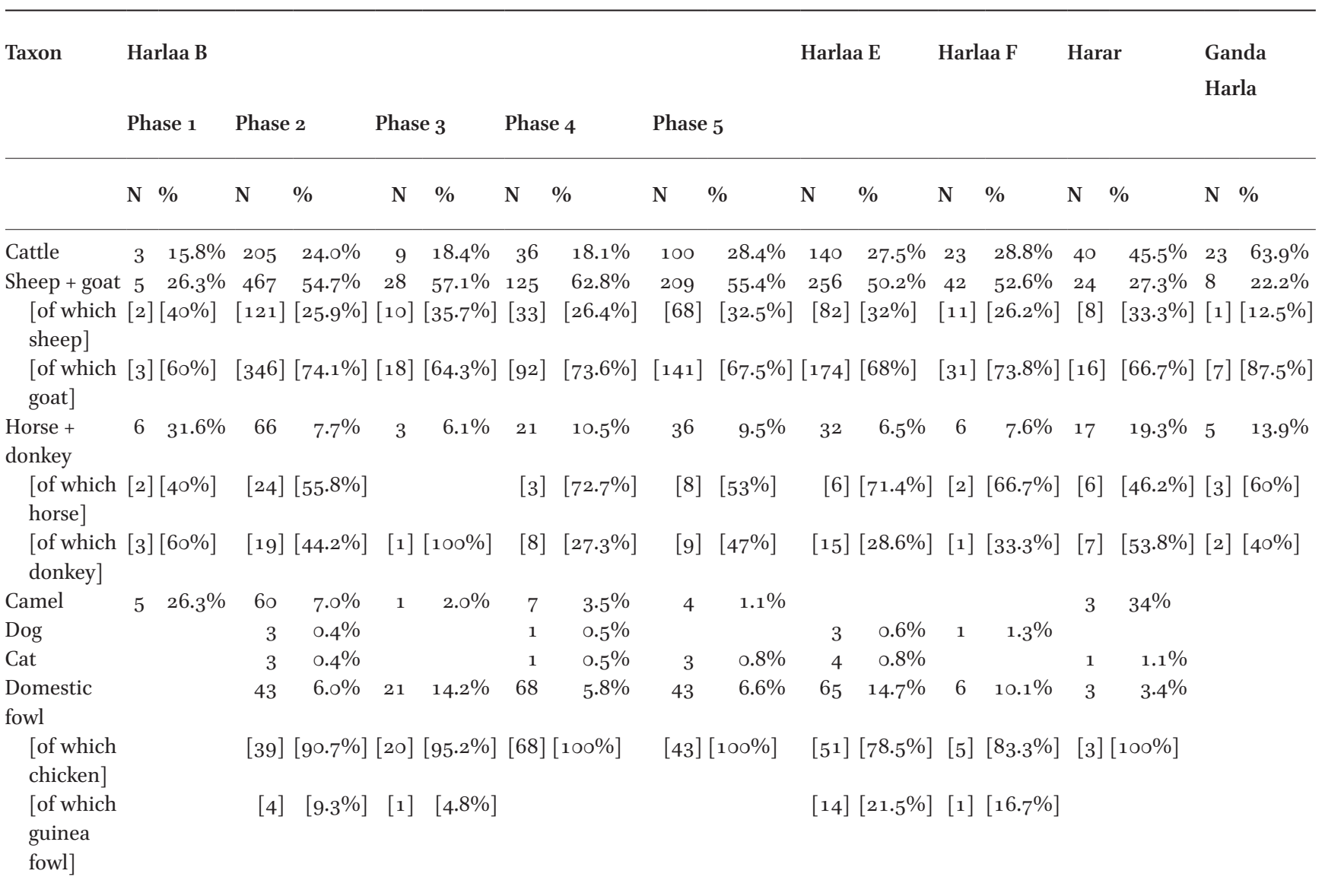


TABLE 6 Additional comparisons of taxa between Harlaa, Harar and Ganda Harla. In this table, domesticates includes both domestic mammals as well as birds. The category 'pack animals' includes both domestic equids as well as camels

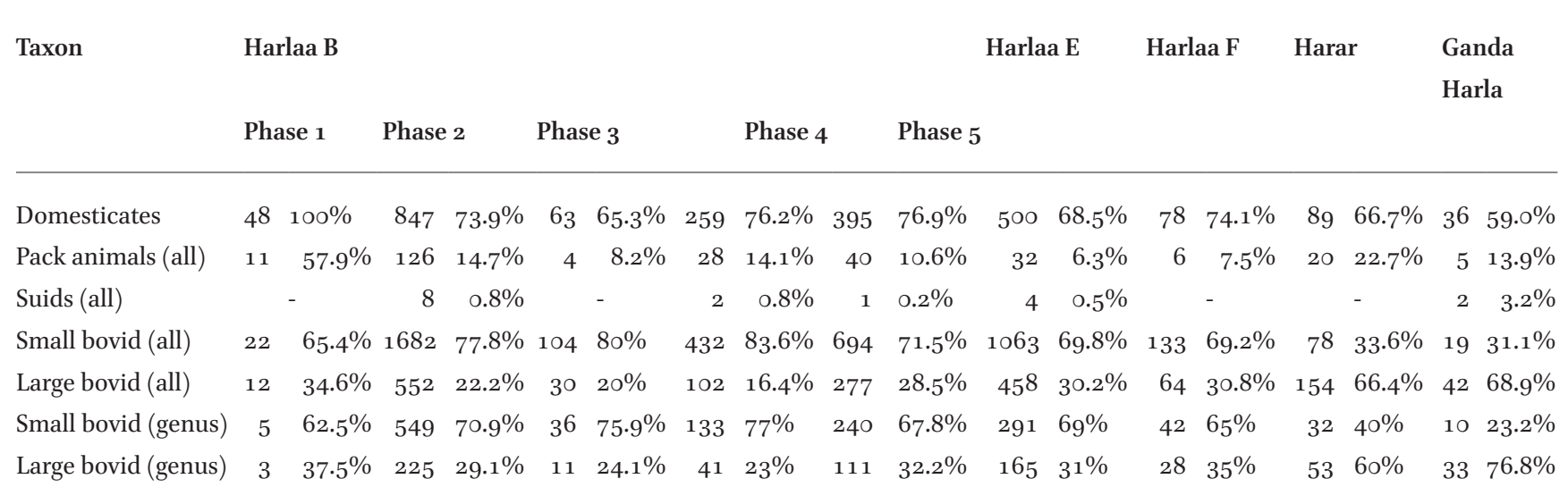

changes when the representation of wild taxa is compared. Both Harar and Ganda Harla show a bias towards the hunting of small bovids in common with samples from Harlaa (Table 4). Where these sites differ is in access to imported animal products, predominately fish, which are absent from both Harar and Ganda Harla, and in the hunting of tortoises which are very rare at Harlaa but frequent at both Harar and Ganda Harla. A second common feature between the hunted fauna of these sites is the representation of suids. While there is no conclusive evidence for the keeping of domestic pigs, both Ganda Harla and Harlaa yielded suid remains. Those which can be identified to genus come from either warthog (Phacochoerus $s p$.) or bushpig (Potamochoerus sp.) and show no clear chronological trend in their consumption.

Wild animals recovered from Harlaa indicate the presence around the site of a fairly open and dry landscape. The most commonly hunted large bovids recovered from Harlaa, Harar and Ganda Harla all favour open terrain and scrub hillsides with the exception of Kobus kob/ellipsiprymnus which are more commonly found at lower elevations such as in valleys and riverine grasslands (Bekele \& Yalden 2013). The hunted small bovids from all three sites favour drier open terrain with a combination of scrub environments, hillsides and grasslands. The non-bovid hunted animals (warthog, bushpig, aardvark, porcupine, hare, gennet, mongoose and leopard) range in habitat from open to scrub habitats. In general, none of the wild taxa recovered from these sites indicates the need for longdistance hunting trips as all share a common overlap in habitats of open and fairly dry grassland or hillsides.

Fish bones recovered from Harlaa (see Table 4) indicate exclusively the presence of oceanic/Red Sea/Gulf of Aden fish on the basis of those elements which could be identified to family or genus. Given the inland location of Harlaa, the fish remains recovered most likely arrived in the form of preserved fish (i.e. salted or dried). Fish remains from phases 1-4 of Area B contain entirely postcranial elements with cranial elements appearing only in phase 5 from this area. Fish remains from Areas $\mathrm{E}$ and $\mathrm{F}$ likewise contain only post-cranial elements. The appearance of some cranial elements in phase 5 of Area B may indicate a change in the preservation techniques of fish imported to Harlaa.

\section{Herd Management Strategies}

The age structure of domestic stock was calculated through assessments of both epiphyseal (post-cranial) fusion as well as from patterns of tooth eruption and wear. The numbers of neonatal (o-2 months) and infant/ juvenile (under c. 6-9 months) elements were recorded for each taxon as well as the numbers of fused and unfused proximal and distal epiphyses of each element recovered from Harlaa, Harar, and Ganda Harla. Elements with multiple fusion centres (e.g. radius) were in the main recovered only as incomplete bone fragments. For those elements where a complete unfused diaphysis was recovered, only the earlier-fusing epiphysis was recorded as providing the minimum age for the individual (Jones \& Sadler2012a, b; Pummel 1987a, b; Zeder 2006).

From both a bulk assessment of fusion and age group survivorship it is apparent that in all contexts the majority of cattle survived into adulthood (c. 80-100\%) (Fig. 4; Supplementary Tables $S_{1}$ to $S_{7}$ ). No remains were recovered from neonatal or infant cattle and only a very small proportion were culled as juveniles (c. o-5\%). This pattern 


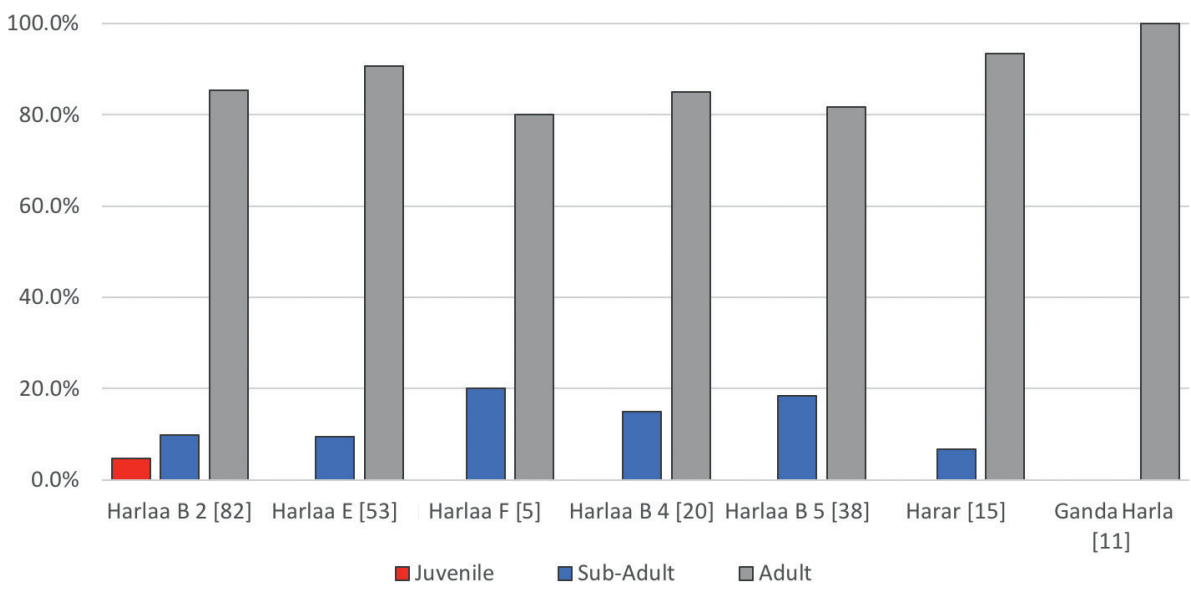

FIGURE 4 Age groups of cattle based on post-cranial fusion data. The NISP of ageable elements for cattle in each sample is given in brackets.

$100.0 \%$

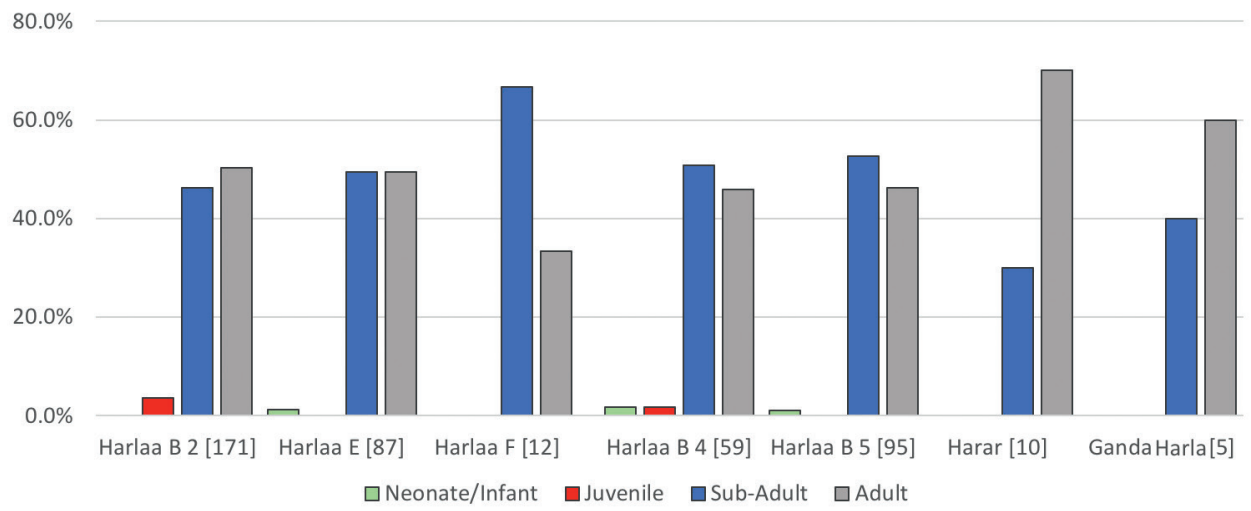

FIGURE 5 Age groups of goats based on post-cranial fusion data. The NISP of ageable goat remains in each sample is given in brackets.

of high adult survivorship suggests that cattle at all three sites were either kept as animals of labour, status, or other secondary products.

Age data on the basis of epiphyseal fusion indicates a different pattern in the management of goats (Capra hircus). Whereas cattle across all three sites and their phases were predominately retained into adulthood, a significant proportion of goats were slaughtered as subadults (Fig. 5; Supplementary Tables S8 to S14). These data indicate a strong bias in the management of goats for their meat, in particular at Harlaa. This can be seen in the high number of sub-adult animal remains, particularly between 18 months and three years of age. At Harlaa c. 50\% of goats were slaughtered prior to three years of age, with c. 15-30\% slaughtered specifically within this 1.5-3 year age window. By contrast, fewer goats from Harar and Ganda Harlaa were slaughtered as subadults with c. $60-70 \%$ of animals surviving into adulthood. While fewer ageable remains were recovered from these sites compared with
Harlaa, those present are sufficient to indicate a more cautious management profile with a greater interest in the perpetuation or increase of livestock numbers.

Too few remains of sheep were recovered from Harar or Ganda Harla to conduct a robust assessment of age. The distribution of sheep from Harlaa by age category (Fig. 6) demonstrates a greater focus in earlier contexts (Phase 2, Area B, Area E and Area F) on the retention of adult animals, while those sub-adult animals that were slaughtered were also kept until very late in their subadult development (Supplementary Tables $S_{15}$ to S19). In samples from later phases (Phases 4 and 5 of Area B), by contrast, the management of sheep indicates a less cautious management with a greater focus on meat production. In these samples, c. $54-58 \%$ of sheep survive into adulthood with a slaughter profile more consistent with that seen from goats at Harlaa than for sheep from earlier contexts.

In comparison with survivorship profiles derived from fusion of post-cranial remains, age profiles were also 


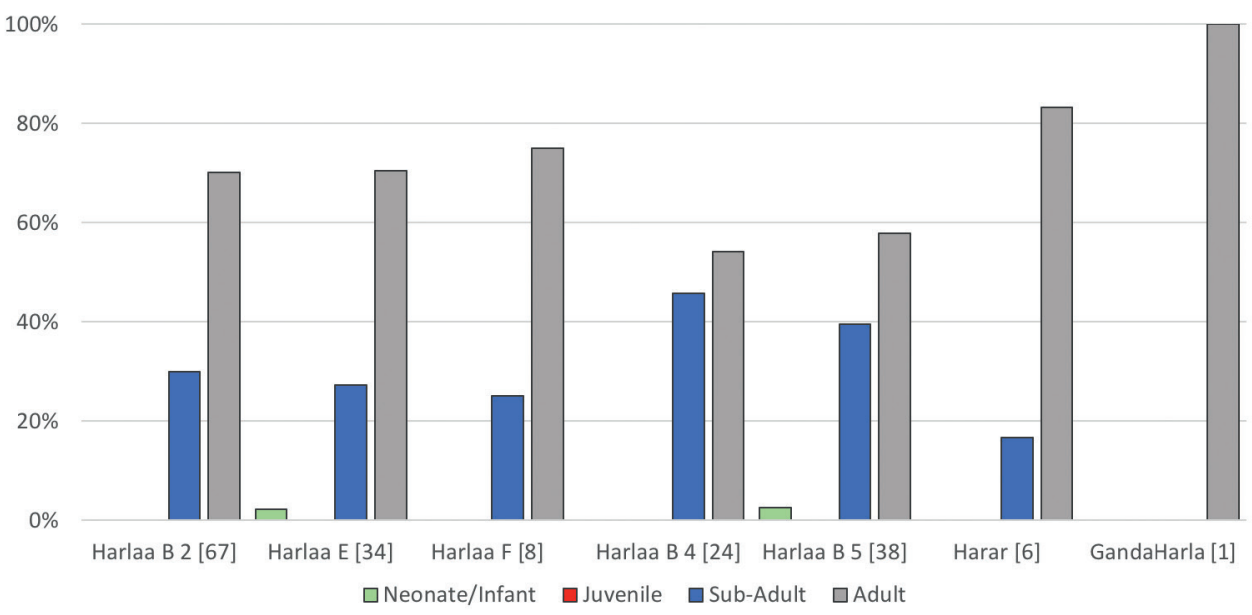

FIGURE 6 Age groups of sheep based on post-cranial fusion data. The NisP of ageable sheep remains in each sample is given in brackets.
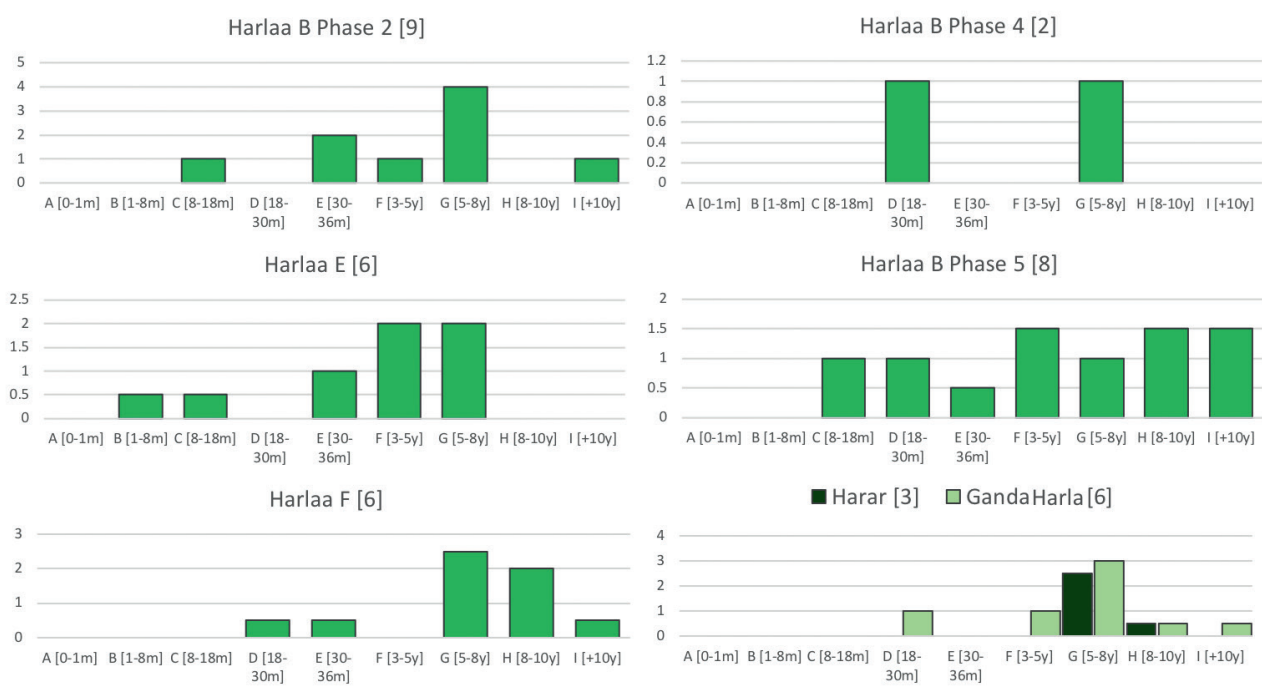

FIGURE 7 Age distribution of cattle on the basis of dental eruption and wear. Teeth have been grouped into age brackets following Halstead (1985). The NISP of ageable remains from each sample is given in brackets.

compiled for cattle, goats and sheep from Harlaa, Harar and Ganda Harla on the basis of dental eruption and wear. Age estimates from tooth wear were made using a variation of the quadratic crown height method (QCHM) modified for bovids by Gaastra (2016) as well as visual tooth-wear ageing (Grant 1982). This form of age profile provides a much narrower estimate of age-at-death for individuals in comparison to post-cranial fusion, as it determines age to within a few months. In keeping with standard practice, teeth have been placed into age groups following Payne (1973) and Halstead (1985).

Comparison of cattle survivorship on the basis of dental eruption and wear (Fig. 7) demonstrates a slightly higher culling of sub-adult animals than was indicated by post-cranial fusion. While survivorship on the basis of fusion indicated c. $80-90 \%$ of cattle from Harlaa surviving beyond 40 months of age, from dental survivorship this is reduced to $50-83 \%$. Most interestingly, dental survivorship indicates the slaughter of c. $11-17 \%$ (vs. $4.8 \%$ postcranial representation of this age group from Harlaa Area B, Phase 2 and absent in all other samples) of cattle within the first year of life from two early contexts at Harlaa (Area B, Phase 2 and Area E). These young animals are not found at Harlaa from the contemporaneous Area $F$ sample, which shows a bias towards the retention of cattle beyond age three $(83 \%$ compared with $66.6 \%$ from both Area B, phase 2 and Area E) compared with any other sample from Harlaa.

Age profile information obtained from dental eruption and wear for goats corresponds well with that seen from post-cranial fusion, while providing additional detail (Fig. 8). The bias towards the slaughter of sub-adult 


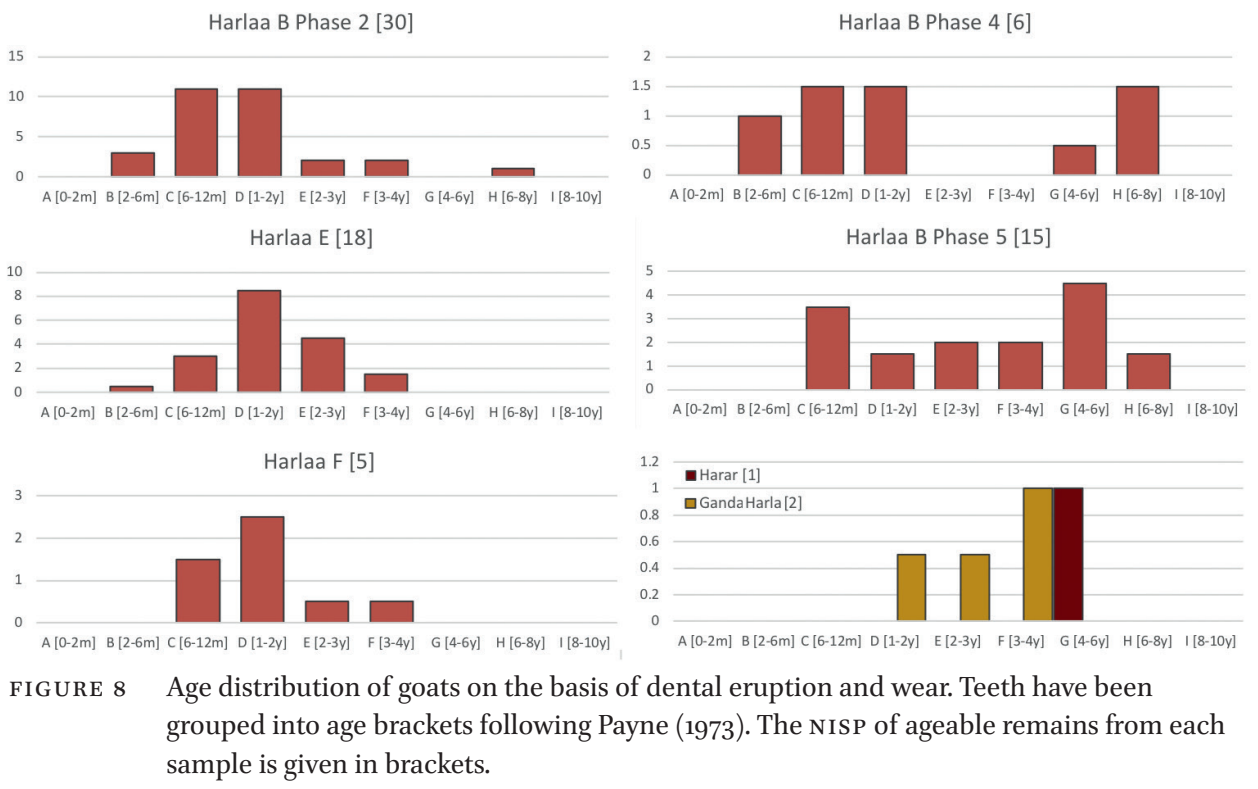

animals seen from post-cranial fusion data is also apparent in data from dental eruption and wear, but also indicates that this bias is stronger than was apparent from post-cranial fusion data, with only c. 10-30\% of animals surviving into adulthood at Harlaa compared with c. $5^{\mathrm{O}}$ $100 \%$ from Harar and Ganda Harla. While not discernible from post-cranial fusion data, it can be seen from dental age data that there is a chronological difference in the exploitation of goats at Harlaa. Circa $30-50 \%$ of goats from Phases 4 and 5, Area B can be seen to survive into adulthood, but the adult proportion from earlier contexts at Harlaa (Area B, Phase 2, Area E and Area F) is less than $10 \%$ with only $3 \%$ surviving beyond four years of age in phase 2 , Area B, and no animals above four years of age in the other two early samples. This suggests strongly that, while a proportion of goats at Harlaa survived into adulthood (up to c. 40 months), very few individuals survived long after this point. Too few mandibles and teeth from sheep were recovered from Harlaa (and none from either Harar or Ganda Harla) to allow for further information on the management of this taxon to be gleaned from analysis of dental eruption and wear.

\section{Sex Proportions of Domesticates}

No sexable pelvic elements of cattle were recovered from either Harar or Ganda Harla (Table 7), and those from Harlaa all come from adult animals (Grigson 1982). With the exception of Phase 2, Area B, male and female animals are equally represented amongst those animals which can be sexed. As with cattle, no sexable pelvic elements of goats were recovered from Harar or Ganda Harla. At
Harlaa, both sub-adult (by fusion status and muscle attachment development) and adult pelvic elements were recovered which could be sexed. In all phases and areas of Harlaa, all recovered female pelvic elements came from young adult or adult animals. Pelvic bones from male goats came from both subadult and adult animals, though in the majority these come from subadult animals. These data, taken together with that from both dental and postcranial age distributions, suggests that extraneous male animals at Harlaa were preferentially culled as subadults with female animals left to survive to a slightly greater age. This is consistent with the age data indications of the management of goats for meat production.

TABLE 7 Sex proportions of cattle (Bos taurus/indicus) and goat (Capra hircus) pelvic girdles for subadult (SA) and adult (A) animals

Bos taurus/indicus

Sex Harlaa Harlaa Harlaa Harlaa Harlaa Harar Ganda $\begin{array}{llllll}\text { B }_{2} & \text { E } & \text { B }_{4} & \text { B }_{5} & \text { F } & \text { Harla }\end{array}$

SA A SA A SA A SA A SA A SA A SA A

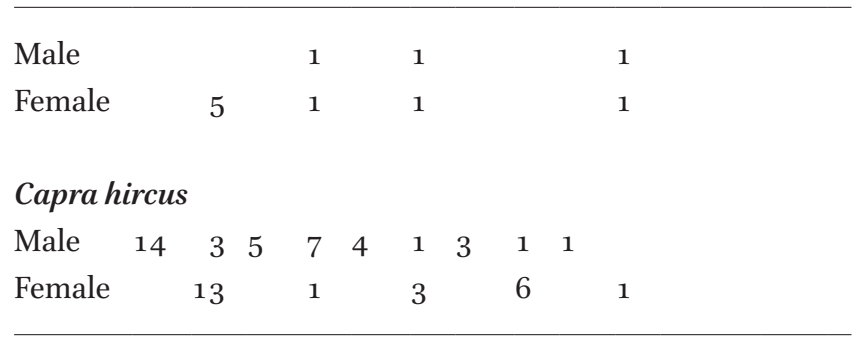




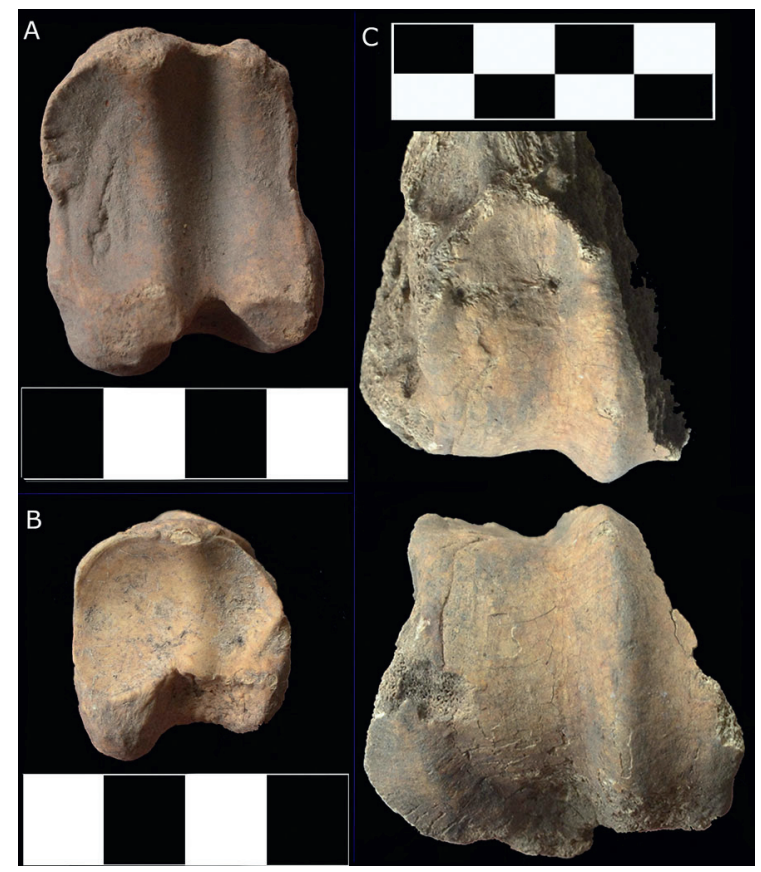

FIGURE 9 Examples of sub-pathological changes to cattle foot bones from Harlaa: (A) phalanx 1 from Area B, phase 5; (B) phalanx 2 from Area E; and (C) distal metatarsal from Area F. Shown here are examples from Harlaa $2018 \mathrm{~B}(3)$ [top left], Harlaa 2019 E(25) [right].

\section{Pathological Bone Modifications}

Muscle attachment development, pathological alterations, and sub-pathological re-modelling were all recorded. Muscle attachment development could be determined for $13 \%$ of identified elements and was graded from light (indicative of subadult individuals) to heavy (indicative of adult or older adult individuals) on a scale of one to five. Pathological alterations to bones were infrequent $(2$ bones or $0.02 \%$ of NISP). The distribution of sub-pathological developments for metacarpals, metatarsals, first phalanges and second phalanges in response to the strain of pulling, or changes to foot bones in response to traction (Fig. 9) were scored following the criteria of the pathological index (PI) as detailed by Bartosiewicz et al. (1997; Bartosieicz 2008). Measurements of the distal ends of metacarpals and metatarsals were also taken where possible.

Foot bones which produced a positive PI score for traction $(2.5$ or greater) were infrequent (Table 8 and 9 ). While the diagnostic foot bones for traction identification were present at both Harar and Ganda Harla, none scored a PI greater than 2.0 and no measurable distal metapodials were recovered from either site. There were no indications of the use of cattle for traction. At Harlaa, samples from Area B (phases 2, 4 and 5) and from Areas E and F all indicate the presence of cattle used for traction (Table 8). However, the presence of these sub-pathological alterations does not permit distinguishing between the potential forms of traction which may have been in use. In general, the repeated practice of pulling excess weight behind the animal can be said to have caused the foot bone alterations present, and may have taken one or more forms, including pulling of carts, or ards or ploughs, or the circular pulling motion to rotate the stone for a stationary grinding apparatus.

\section{Butchery}

Cut marks are relatively infrequent at Harlaa (311 elements, or 3.9\%) at Harar (11 elements, 3.3\%), and Ganda Harla (1 element, o.9\%). The scarcity of butchery marks is unsurprising, as with the exception of butchery using heavy knives to sever and portion bones, cut marks produced during the processing of carcasses are generally infrequent as the aim of the butcher is to avoid direct contact with bones which will dull butchery tools (Seetah 2007). Therefore, the majority of butchery marks can be considered as 'accidental' indicators of the process of carcass skinning, disarticulation and defleshing. These marks relate to three stages in the processing of carcasses. The first stage is skinning and evisceration, in which the skin and internal organs of the animal are removed

TABLE 8 Distribution of PI values from cattle foot bones

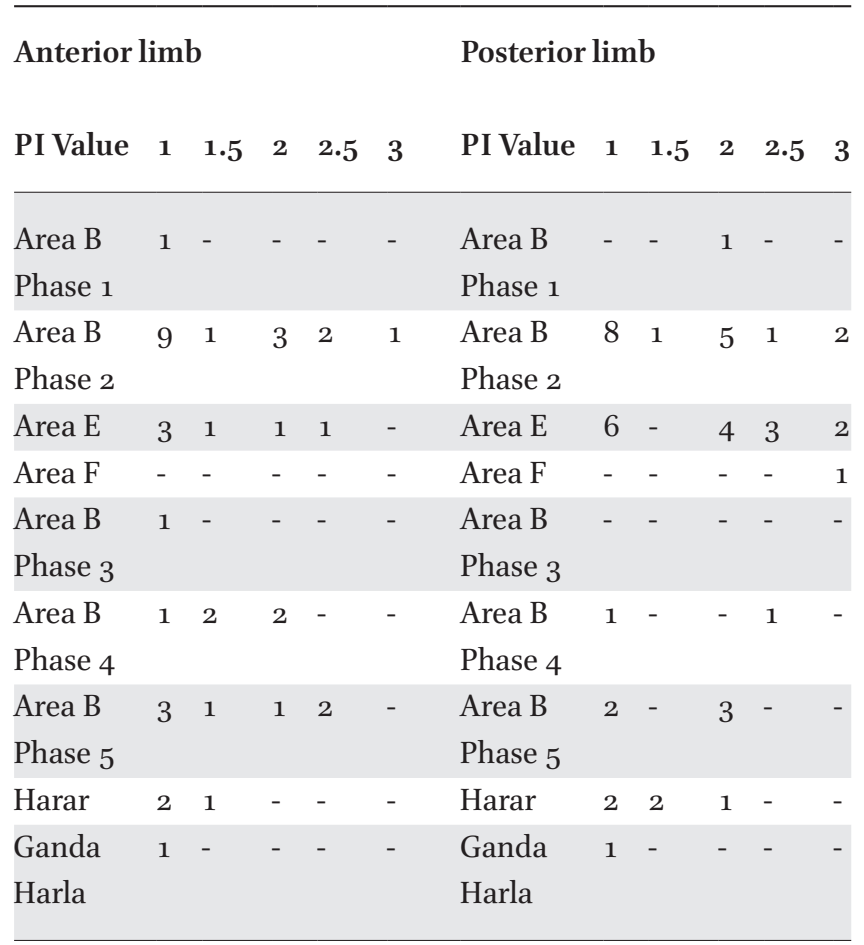


TABLE 9 Osteometric data for distal metapodials recovered from Harlaa. Those metapodials which demonstrated a positive traction index (e/D1) following Lin et al. (2016) are given in bold. The measurement $(\mathrm{mm})$ of the distal breadth of the metapodial following von den Driesch (1976) is given here in as it has been used to determine the probable sex of the animal

Anterior limb: Metacarpal

Posterior limb: Metatarsal

$\begin{array}{llll}\text { Area } & \begin{array}{l}\text { Distal Sex e/D1 Area } \\ \text { breadth }\end{array} & \begin{array}{l}\text { Distal Sex e/D1 } \\ \text { breadth } \\ (B d)\end{array} & (B d)\end{array}$

\begin{tabular}{|c|c|c|c|c|c|c|c|}
\hline $\begin{array}{l}\text { Area B } \\
\text { Phase } 2\end{array}$ & $5^{1.5}$ & $\mathrm{~F}$ & o.637 & $\begin{array}{l}\text { Area B } \\
\text { Phase } 2\end{array}$ & $5^{1.9}$ & $\mathrm{~F}$ & 0.760 \\
\hline $\begin{array}{l}\text { Area B } \\
\text { Phase } 2\end{array}$ & $5^{0.4}$ & $\mathrm{~F}$ & о. 636 & $\begin{array}{l}\text { Area B } \\
\text { Phase } 2\end{array}$ & 55.0 & M & 0.709 \\
\hline $\begin{array}{l}\text { Area B } \\
\text { Phase } 2\end{array}$ & $5^{6.3}$ & $\mathrm{M}$ & 0.611 & $\begin{array}{l}\text { Area B } \\
\text { Phase } 2\end{array}$ & 53.2 & $?$ & 0.706 \\
\hline $\begin{array}{l}\text { Area B } \\
\text { Phase } 2\end{array}$ & $5^{6.8}$ & $\mathrm{M}$ & 0.717 & $\begin{array}{l}\text { Area B } \\
\text { Phase } 2\end{array}$ & 48.9 & $\mathrm{~F}$ & 0.648 \\
\hline $\begin{array}{l}\text { Area B } \\
\text { Phase } 2\end{array}$ & $5^{6.8}$ & M & 0.604 & Area E & $5^{8.9}$ & $\mathrm{M}$ & 0.716 \\
\hline \multirow[t]{3}{*}{ Area E } & $5^{\circ} .7$ & $\mathrm{~F}$ & 0.619 & Area E & $55 \cdot 7$ & $\mathrm{M}$ & 0.638 \\
\hline & & & & Area E & 53.5 & $?$ & 0.757 \\
\hline & & & & Area F & 54.8 & $\mathrm{M}$ & 0.783 \\
\hline $\begin{array}{l}\text { Area B } \\
\text { Phase } 4\end{array}$ & $5^{\circ} .9$ & $\mathrm{~F}$ & 0.622 & $\begin{array}{l}\text { Area B } \\
\text { Phase } 4\end{array}$ & - & - & 0.749 \\
\hline $\begin{array}{l}\text { Area B } \\
\text { Phase } 5\end{array}$ & $5^{2.4}$ & $?$ & 0.641 & $\begin{array}{l}\text { Area B } \\
\text { Phase } 5\end{array}$ & $5^{\circ} .7$ & $\mathrm{~F}$ & 0.594 \\
\hline $\begin{array}{l}\text { Area B } \\
\text { Phase } 5\end{array}$ & $55 \cdot 3$ & M & 0.747 & $\begin{array}{l}\text { Area B } \\
\text { Phase } 5\end{array}$ & $54 \cdot 4$ & M & 0.701 \\
\hline
\end{tabular}

(Figs. 10 and 11). The second stage is disarticulation of the carcass into either individual elements or a set of butchery units. The third stage is the removal of meat from bones. This is known as 'defleshing' or "filleting' and can occur either before or after cooking (Fig. 12). The identification of which stage in carcass processing is represented by a particular butchery mark (or marks) has been determined in reference to experimental butchery studies by Binford (1981), Nilssen (2000) and Seetah (2007). Butchery marks observed on animal ones from Harlaa, Harar and Ganda Harla was recorded as to the location, direction and type of butchering mark. These were categorized according to the three main stages of butchery. In comparisons of butchery practices between sites (and site phases) the most diagnostic stage was carcass disarticulation. An overview of disarticulation marks identified from Harlaa, Harar and Ganda Harla can be seen in Tables 10 to 13 .
A common pattern of segmenting carcasses can be seen. Following the removal of entrails and the skinning of carcasses, the head was removed primarily through slices to free it from the first cervical vertebra (atlas). This was in the majority accessed from the dorsal side of the animal for both small and large animals. Less commonly, and primarily with small bovids, the head was removed by chopping through the cervical vertebrae (Fig. 13). The anterior limb shows two areas of segmentation - from division of the shoulder through the removal of the humerus from the scapula or from the division of the carcass at the elbow by separating the distal humerus from the radius and ulna (Figs. 14 and 15). The hind limb indicates only the separation of this limb at the hip by the removal of the femur from the pelvis. In some cases, however, this appears to have been achieved by chopping the pelvic girdle through the pubis (in large and small bovids) or through the illial and ischial shafts to remove the acetabulum along with the posterior limb (Fig. 16).

Butchery was conducted using both small and large knives, with large knives appearing to be more common in the butchery of larger animals. However, the segmentation of the axial skeleton in both small bovids and large animals follows a mix of approaches and the use of both larger knives for chopping as well as smaller slicing methods. Moreover, skinning can be seen to take place at different portions of the foot regardless of the body size of the animal, with small bovids indicating skinning marks on the first or second phalange either from the anterior or posterior limb. This is also seen with large bovids and large mammals (equids and camels) albeit with a smaller sample size. The overall impression given by butchery marks is of a pattern of individualized rather than professional butchery, with different individuals having different methods and different choices in or access to butchery equipment.

Only one butchered element was recovered from Ganda Harla, a cattle calcaneus which was disarticulated by fine slices. 11 elements from Harar contexts had traces of butchery, of these 3 were traces of filleting (both small and large bovids). The remaining 8 elements were from both small and large bovids and predominately indicated disarticulation by fine slices with the exception of one sheep illial wing which was chopped through in order to remove the sacrum and one cattle illial wing which was likewise chopped through for the removal of the sacrum (Fig. 16). This pattern of disarticulation of the hindlimb and the removal of the sacrum (to divide the pelvis) was also seen at Harlaa, although alternative methods of carcass dismemberment were also indicated at Harlaa (chopping through the pelvis around the acetabulum, removal of the sacrum 


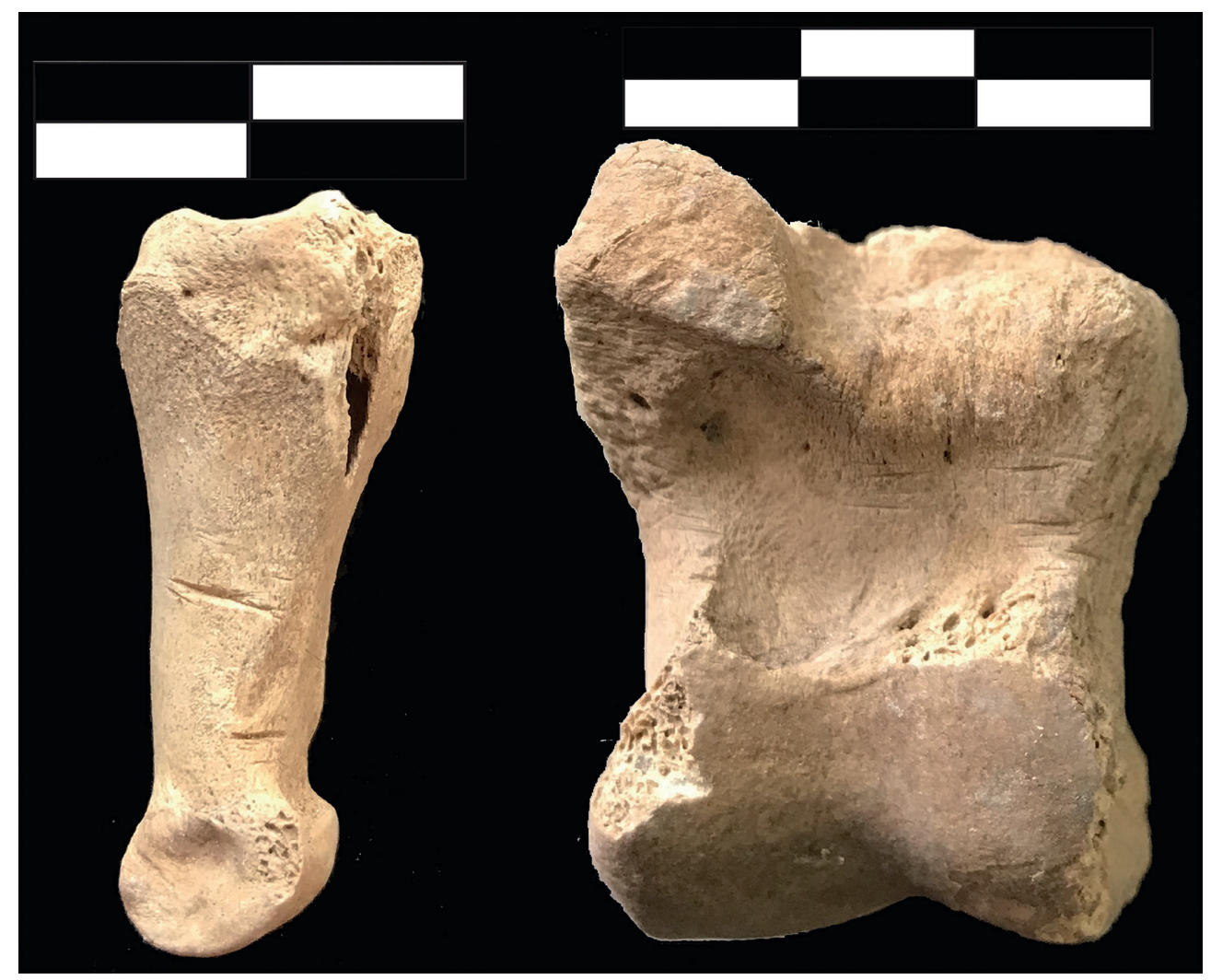

FIGURE 10 Examples of marks associated with skinning found on foot bones from Harlaa, Harar and Ganda Harla. Shown here are examples from Harlaa 2017 (B)14 [left] and Harlaa 2018 B(22) [right].

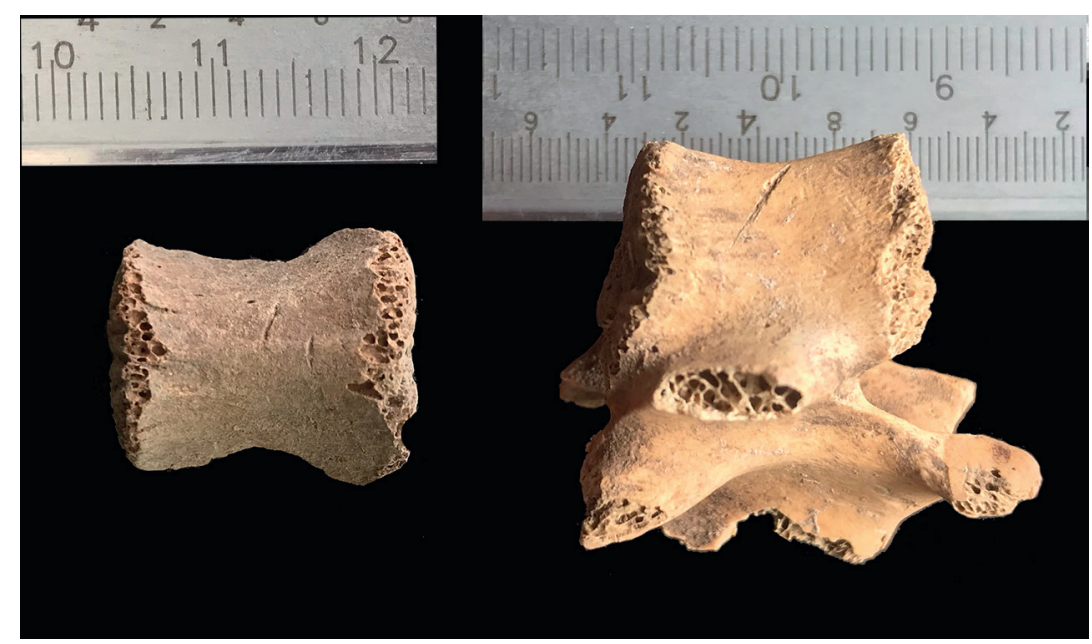

FIGURE 11 Examples of butchery marks left by the evisceration process on vertebrae from Harlaa, Harar and Ganda Harla. Shown here are examples from Harlaa 2017 B (7) [left] and Harlaa 2019 E(29) [right]. 


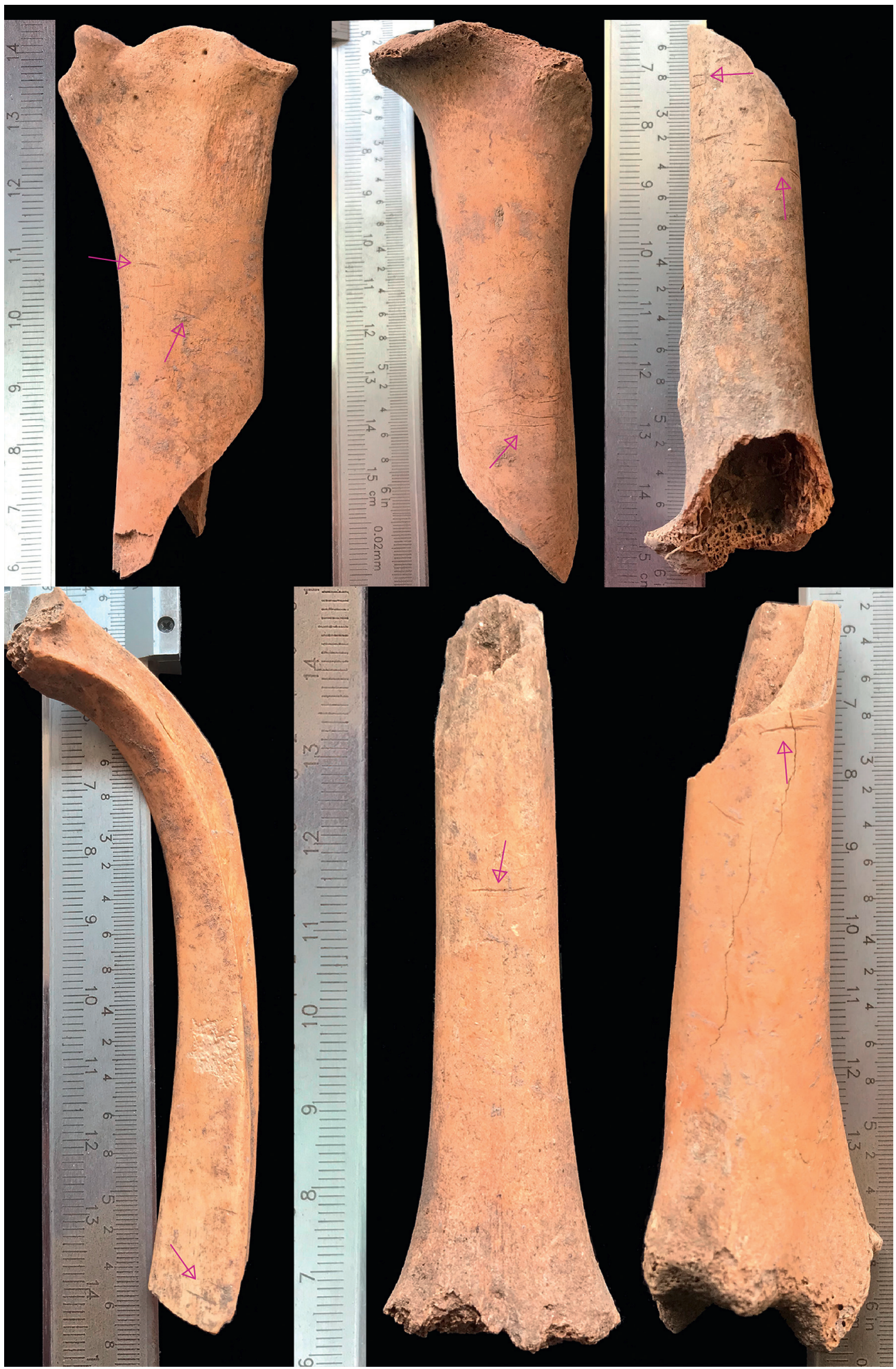

FIGURE 12 Examples of filleting marks found on material from Harlaa, Harar and Ganda Harla. Given the faint nature of filleting marks, these have been highlighted with arrows. Shown here are examples from (from top left) Harlaa 2018 B(10), 2018 B(10), 2018 (B)9, 2019 E(24), 2019 E(7) and $2019 \mathrm{E}(25)$. 


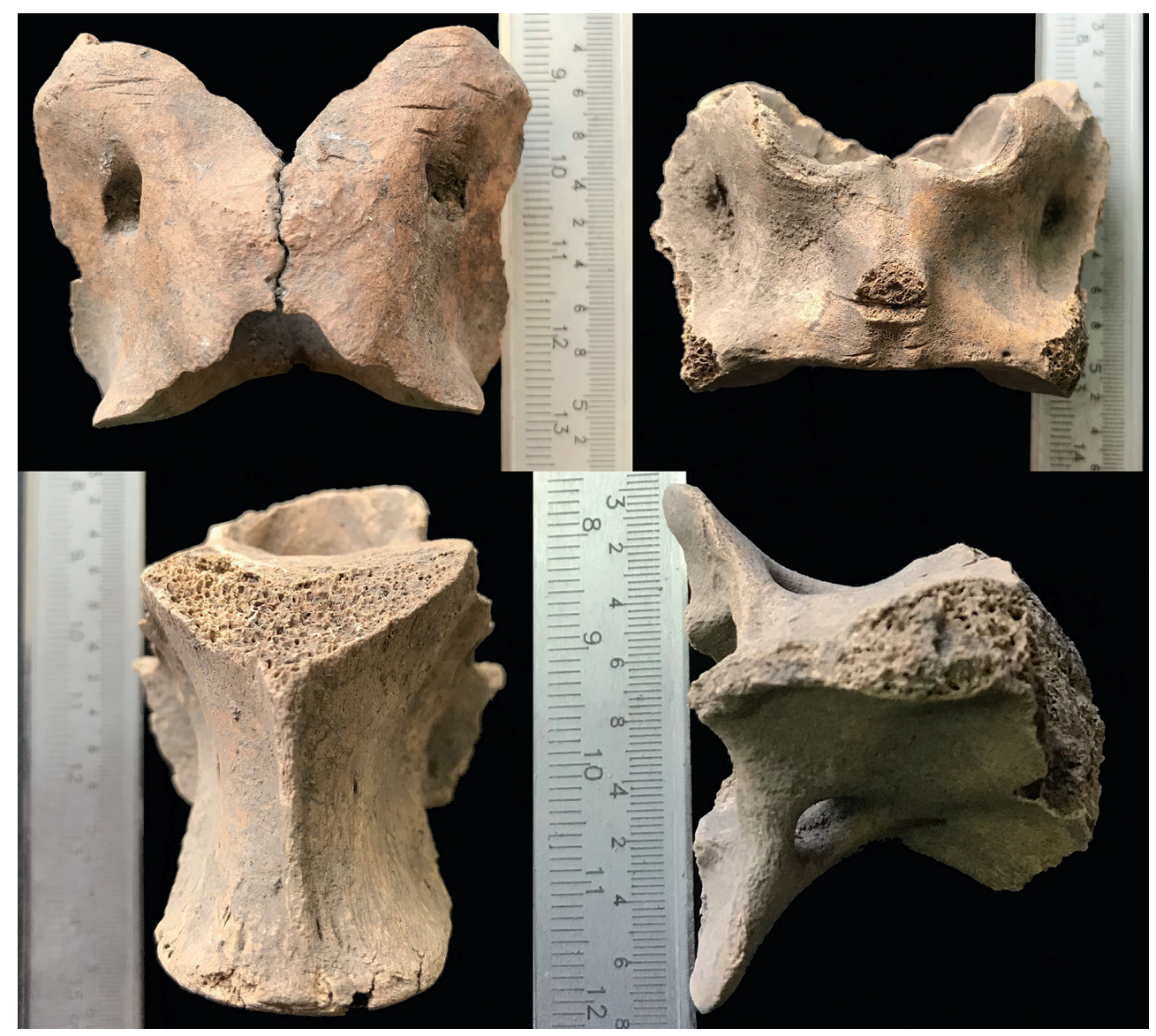

FIGURE 13 Examples of the multiple approaches to decapitation of bovids on the material from Harlaa illustrating disarticulation of the atlas from the skull by means of fine slices (top) and chops through the other cervical vertebrae further down the neck (bottom). Shown here are examples from (from top left) Harlaa $2018 \mathrm{~B}(7), 2017 \mathrm{~B}(4), 2017 \mathrm{~B}(4)$ and $2018 \mathrm{~B}(5)$.

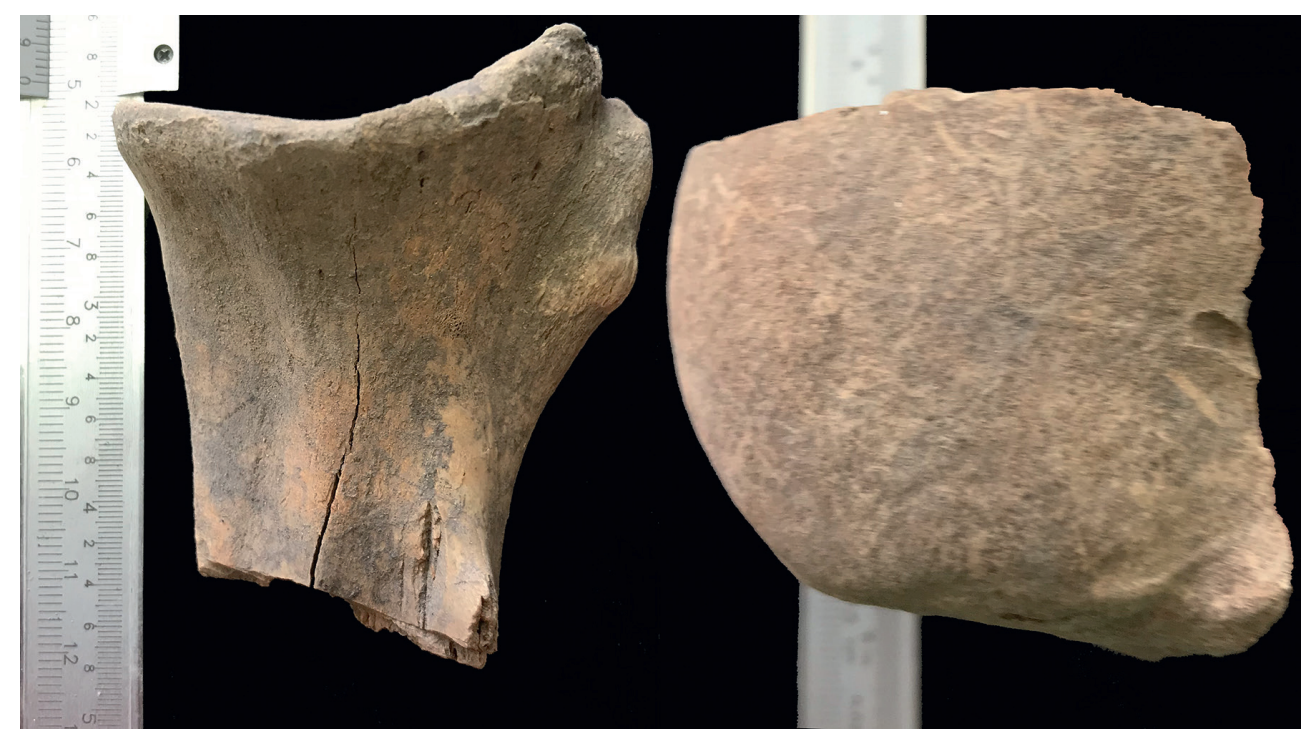

FIGURE 14 Examples of the severing of the shoulder with chops through the neck of the scapula (left) and the head of the humerus (right). Shown here are examples from Harlaa $2018 \mathrm{~B}(9)$ [left] and Harlaa $2018 \mathrm{~B}(11)$ [right]. 
TABLE 10 Details of butchery evidence for carcass disarticulation on material recovered from phases 1 and 2 of Area B at Harlaa. In addition to these were recovered one bones with traces of filleting from phase 1 and from phase 2 four elements with traces of evisceration (the removal of entrails), 8 with evidence of skinning and 32 with evidence of filleting

\begin{tabular}{|c|c|c|c|c|c|c|}
\hline Sample & Process & Taxon & Element & Portion & Location & Mark type \\
\hline $\mathrm{B} / 1$ & Disarticulation & Ovis aries & Metatarsal & Proximal & Anterior face & Fine slices \\
\hline $\mathrm{B} / 1$ & Disarticulation & Camellus sp. & Humerus & Distal & Lateral faces & Chopped through \\
\hline $\mathrm{B} / 1$ & Filleting & Small bovid & Lumbar & Centrum & Ventral face & Fine slices \\
\hline $\mathrm{B} / 2$ & Severing throat & Small bovid & Hyoid & Stylohyoid & Posterior & Thick slice \\
\hline $\mathrm{B} / 2$ & Disarticulation & Caprahircus & Humerus & Proximal & Capitus & Chopped through \\
\hline $\mathrm{B} / 2$ & Disarticulation & Small bovid & Humerus & Proximal & Capitus & Chopped through \\
\hline $\mathrm{B} / 2$ & Disarticulation & Nanger granti & Axis & Centrum & Medial & Chopped through \\
\hline $\mathrm{B} / 2$ & Disarticulation & Small bovid & Sacrum & Centrum & Medial & Chopped through \\
\hline $\mathrm{B} / 2$ & Rib removal & Small bovid & Thoraxic & Centrum & Lateral & Chopped through \\
\hline $\mathrm{B} / 2$ & Rib removal & Small bovid & Rib & Shaft & Neck margins & Chopped through \\
\hline $\mathrm{B} / 2$ & Tongue removal & Small bovid & Mandible & Ramus & Medial & Fine slices \\
\hline $\mathrm{B} / 2$ & Tongue removal & Small bovid & Mandible & Ramus & Medial & Fine slices \\
\hline $\mathrm{B} / 2$ & Tongue removal & Small bovid & Hyoid & Stylohyoid & Medial face & Fine slices \\
\hline $\mathrm{B} / 2$ & Tongue removal & Small bovid & Hyoid & Stylohyoid & Medial face & Fine slices \\
\hline $\mathrm{B} / 2$ & Tongue removal & Small bovid & Hyoid & Stylohyoid & Medial face & Fine slices \\
\hline $\mathrm{B} / 2$ & Disarticulation & Bos sp. & Humerus & Distal & Posterior face & Fine slices \\
\hline $\mathrm{B} / 2$ & Disarticulation & Bos sp. & Tibia & Distal & Anterior face & Fine slices \\
\hline $\mathrm{B} / 2$ & Disarticulation & Large bovid & Ulna & Proximal & Anterior margin & Fine slices \\
\hline $\mathrm{B} / 2$ & Disarticulation & Bos sp. & Metacarpal & Proximal & Anterior face & Fine slices \\
\hline $\mathrm{B} / 2$ & Disarticulation & Bossp. & Astragalus & Distal & Lateral & Chopped through \\
\hline $\mathrm{B} / 2$ & Disarticulation & Bos sp. & Humerus & Proximal & Capitus & Chopped through \\
\hline $\mathrm{B} / 2$ & Disarticulation & Bossp. & Humerus & Distal & Trochlea & Chopped through \\
\hline $\mathrm{B} / 2$ & Disarticulation & Kobus sp. & Humerus & Distal & Trochlea & Chopped through \\
\hline $\mathrm{B} / 2$ & Disarticulation & Bossp. & Innominate & Shaft & Ischium, Pubis & Chopped through \\
\hline $\mathrm{B} / 2$ & Disarticulation & Bossp. & Scapula & Neck & Dorsal & Chopped through \\
\hline $\mathrm{B} / 2$ & Disarticulation & Bos sp. & Femur & Proximal & Capitus & Chopped through \\
\hline $\mathrm{B} / 2$ & Disarticulation & Bos sp. & Femur & Proximal & Capitus & Chopped through \\
\hline $\mathrm{B} / 2$ & Rib removal & Large bovid & Rib & Shaft & Neck margins & Chopped through \\
\hline $\mathrm{B} / 2$ & Rib removal & Large bovid & Rib & Shaft & Neck margins & Chopped through \\
\hline $\mathrm{B} / 2$ & Rib removal & Large bovid & Rib & Shaft & Neck margins & Chopped through \\
\hline $\mathrm{B} / 2$ & Rib removal & Large bovid & Rib & Shaft & Neck margins & Chopped through \\
\hline $\mathrm{B} / 2$ & Rib removal & Large bovid & Rib & Shaft & Neck margins & Chopped through \\
\hline $\mathrm{B} / 2$ & Disarticulation & Large bovid & Cervical & Centrum & Dorsal & Chopped through \\
\hline $\mathrm{B} / 2$ & Disarticulation & Equus caballus & Cervical & Centrum & Dorsal & Chopped through \\
\hline $\mathrm{B} / 2$ & Disarticulation & Camellus sp. & Atlas & Centrum & Anterior & Fine slices \\
\hline $\mathrm{B} / 2$ & Tongue removal & Large bovid & Hyoid & Stylohyoid & Medial face & Fine slices \\
\hline $\mathrm{B} / 2$ & Tongue removal & Camellus sp. & Mandible & Ramus & Medial & Fine slices \\
\hline $\mathrm{B} / 2$ & Disarticulation & Galliform & Humerus & Distal & Lateral & Fine slices \\
\hline
\end{tabular}


TABLE 11 Details of butchery evidence for carcass disarticulation on material recovered from Areas E and F at Harlaa. In addition to these were recovered two bones with traces of evisceration, 12 with traces of skinning and 37 with traces of filleting from Area E. From Area F were additionally five elements with traces of filleting

\begin{tabular}{|c|c|c|c|c|c|c|}
\hline Sample & Process & Taxon & Element & Portion & Location & Mark type \\
\hline $\mathrm{E}$ & Disarticulation & Capra hircus & Innominate & Illium & Wing & Chopped through \\
\hline $\mathrm{E}$ & Disarticulation & Small bovid & Innominate & Illium & Wing & Chopped through \\
\hline $\mathrm{E}$ & Disarticulation & Caprahircus & Scapula & Neck & Anterior & Fine slices \\
\hline $\mathrm{E}$ & Disarticulation & Caprahircus & Scapula & Neck & Ventral & Fine slices \\
\hline $\mathrm{E}$ & Disarticulation & Capra hircus & Scapula & Neck & Ventral & Fine slices \\
\hline $\mathrm{E}$ & Disarticulation & Ovis aries & Humerus & Distal & Anterior face & Fine slices \\
\hline $\mathrm{E}$ & Disarticulation & Capra hircus & Humerus & Distal & Posterior face & Fine slices \\
\hline $\mathrm{E}$ & Disarticulation & Ovis aries & Humerus & Distal & Posterior face & Fine slices \\
\hline $\mathrm{E}$ & Disarticulation & Ovis aries & Radius & Proximal & Anterior face & Fine slices \\
\hline $\mathrm{E}$ & Disarticulation & Ovis aries & Radius & Proximal & Anterior face & Fine slices \\
\hline $\mathrm{E}$ & Disarticulation & Small bovid & Femur & Shaft & Anterior & Fine slices \\
\hline $\mathrm{E}$ & Disarticulation & Dorcatragus & Femur & Proximal & Anterior & Fine slices \\
\hline $\mathrm{E}$ & Disarticulation & Capra hircus & Atlas & Centrum & Ventral face & Fine slices \\
\hline $\mathrm{E}$ & Disarticulation & Small bovid & Cervical & Centrum & Dorsal & Chopped through \\
\hline $\mathrm{E}$ & Disarticulation & Small bovid & Thoraxic & Centrum & Ventral & Chopped through \\
\hline $\mathrm{E}$ & Rib removal & Small bovid & Thoraxic & Centrum & Ventral, lateral & Chopped through \\
\hline $\mathrm{E}$ & Rib removal & Small bovid & Thoraxic & Centrum & Ventral, lateral & Chopped through \\
\hline $\mathrm{E}$ & Disarticulation & Small bovid & Lumbar & Centrum & Ventral & Chopped through \\
\hline $\mathrm{E}$ & Disarticulation & Small bovid & Lumbar & Centrum & Ventral & Chopped through \\
\hline $\mathrm{E}$ & Rib removal & Small bovid & Rib & Shaft & Neck margins & Chopped through \\
\hline $\mathrm{E}$ & Rib removal & Small bovid & Rib & Shaft & Neck margins & Chopped through \\
\hline $\mathrm{E}$ & Severing throat & Small bovid & Hyoid & Stylohyoid & Posterior & Thick slice \\
\hline $\mathrm{E}$ & Disarticulation & Bos sp. & Humerus & Distal & Trochlea & Chopped through \\
\hline $\mathrm{E}$ & Disarticulation & Bos sp. & Humerus & Distal & Trochlea & Chopped through \\
\hline $\mathrm{E}$ & Disarticulation & Bossp. & Humerus & Distal & Anterior & Fine slices \\
\hline $\mathrm{E}$ & Disarticulation & Bos sp. & Humerus & Distal & Anterior & Fine slices \\
\hline $\mathrm{E}$ & Disarticulation & Bos sp. & Tibia & Proximal & Lateral & Fine slices \\
\hline $\mathrm{E}$ & Disarticulation & Bos sp. & Metatarsal & Distal & Lateral & Fine slices \\
\hline $\mathrm{E}$ & Disarticulation & Bos sp. & Astragalus & Distal & Posterior face & Fine slices \\
\hline $\mathrm{E}$ & Disarticulation & Bos sp. & Calcaneus & Proximal & Lateral face & Fine slices \\
\hline $\mathrm{E}$ & Disarticulation & Large bovid & Cervical & Centrum & Ventral & Chopped through \\
\hline $\mathrm{E}$ & Rib removal & Large bovid & Rib & Shaft & Neck margins & Chopped through \\
\hline $\mathrm{E}$ & Rib removal & Large bovid & Rib & Shaft & Neck margins & Chopped through \\
\hline $\mathrm{E}$ & Rib removal & Large bovid & Rib & Shaft & Neck margins & Chopped through \\
\hline $\mathrm{E}$ & Rib removal & Large bovid & Rib & Shaft & Neck margins & Chopped through \\
\hline $\mathrm{F}$ & Tongue removal & Equus sp. & Hyoid & Stylohyoid & Medial face & Fine slices \\
\hline $\mathrm{F}$ & Disarticulation & Capra hircus & Atlas & Centrum & Ventral face & Fine slices \\
\hline $\mathrm{F}$ & Disarticulation & Capra hircus & Tibia & Distal & Lateral, anterior & Fine slices \\
\hline
\end{tabular}


TABLE 12 Details of butchery evidence for carcass disarticulation on material recovered from phases 3 and 4 of Area B at Harlaa. In addition to these were recovered three elements with traces of filleting from phase 3 and from phase 4 two elements with traces of skinning and 14 with traces of filleting

\begin{tabular}{|c|c|c|c|c|c|c|}
\hline Sample & Process & Taxon & Element & Portion & Location & Mark type \\
\hline $\mathrm{B} / 3$ & Disarticulation & Gallus gallus & Tibiotarsus & Distal & Lateral & Fine slices \\
\hline $\mathrm{B} / 3$ & Disarticulation & Capra hircus & Humerus & Distal & Posterior face & Fine slices \\
\hline $\mathrm{B} / 3$ & Disarticulation & Gazella dorcas & Radius & Proximal & Medial face & Fine slices \\
\hline $\mathrm{B} / 3$ & Disarticulation & Ovis aries & Femur & Proximal & Medial & Chopped through \\
\hline $\mathrm{B} / 3$ & Disarticulation & Small bovid & Tibia & Distal & Shaft & Chopped through \\
\hline $\mathrm{B} / 3$ & Disarticulation & Small bovid & Lumbar & Centrum & Anterior & Chopped through \\
\hline $\mathrm{B} / 3$ & Rib removal & Small bovid & Rib & Neck & Anterior & Fine slices \\
\hline $\mathrm{B} / 3$ & Rib removal & Small bovid & Rib & Neck & Anterior & Thick slices \\
\hline $\mathrm{B} / 4$ & Disarticulation & Nanger granti & Humerus & Distal & Trochlea & Chopped through \\
\hline $\mathrm{B} / 4$ & Disarticulation & Ovis aries & Humerus & Distal & Anterior & Fine slices \\
\hline $\mathrm{B} / 4$ & Disarticulation & Capra hircus & Humerus & Distal & Lateral & Fine slices \\
\hline $\mathrm{B} / 4$ & Disarticulation & Ovis aries & Humerus & Distal & All faces & Fine slices \\
\hline $\mathrm{B} / 4$ & Disarticulation & Small bovid & Innominate & Illium & Wing & Chopped through \\
\hline $\mathrm{B} / 4$ & Disarticulation & Ovis aries & Innominate & \multicolumn{2}{|c|}{ Ischium+ Illium Shafts } & Chopped through \\
\hline $\mathrm{B} / 4$ & Disarticulation & Small bovid & Axis & Centrum & Anterior & Chopped through \\
\hline $\mathrm{B} / 4$ & Disarticulation & Small bovid & Lumbar & Centrum & Ventral & Chopped through \\
\hline $\mathrm{B} / 4$ & Disarticulation & Bos sp. & Innominate & Pubis & Symphysis & Chopped through \\
\hline $\mathrm{B} / 4$ & Disarticulation & Bos sp. & Tibia & Distal & Shaft & Chopped through \\
\hline $\mathrm{B} / 4$ & Disarticulation & Large bovid & Tibia & Proximal & Tibial crest & Chopped through \\
\hline $\mathrm{B} / 4$ & Disarticulation & Large bovid & Thoraxic & Centrum & Ventral & Chopped through \\
\hline $\mathrm{B} / 4$ & Disarticulation & Large mammal & Thoraxic & Centrum & Ventral & Chopped through \\
\hline $\mathrm{B} / 4$ & Rib removal & Large bovid & Rib & Neck & Anterior & Thick slices \\
\hline $\mathrm{B} / 4$ & Rib removal & Large bovid & Rib & Neck & Neck margins & Chopped through \\
\hline $\mathrm{B} / 4$ & Disarticulation & Gallus gallus & Humerus & Distal & Lateral & Fine slices \\
\hline
\end{tabular}

TABLE 13 Details of butchery evidence for carcass disarticulation on material recovered from phases 5 of Area B at Harlaa. In addition to these were recovered one bone with traces of evisceration, 7 with traces of skinning and 23 with traces of filleting

\begin{tabular}{|c|c|c|c|c|c|c|}
\hline Sample & Process & Taxon & Element & Portion & Location & Mark Type \\
\hline $\mathrm{B} / 5$ & Disarticulation & Capra hircus & Scapula & Proximal & Ventral & Fine slices \\
\hline $\mathrm{B} / 5$ & Disarticulation & Capra hircus & Humerus & Distal & Anterior & Fine slices \\
\hline $\mathrm{B} / 5$ & Disarticulation & Small bovid & Humerus & Proximal & Anterior & Fine slices \\
\hline $\mathrm{B} / 5$ & Disarticulation & Ovis aries & Radius & Proximal & Anterior & Fine slices \\
\hline $\mathrm{B} / 5$ & Disarticulation & Small bovid & Radius & Proximal & Anterior & Fine slices \\
\hline $\mathrm{B} / 5$ & Disarticulation & Capra hircus & Ulna & Proximal & Anterior & Fine slices \\
\hline $\mathrm{B} / 5$ & Disarticulation & Capra hircus & Metacarpal & Proximal & Posterior & Fine slices \\
\hline $\mathrm{B} / 5$ & Disarticulation & Ovis aries & Astragalus & Distal & Posterior & Fine slices \\
\hline $\mathrm{B} / 5$ & Disarticulation & Ovis aries & Calcaneus & Proximal & Malleolar & Chopped through \\
\hline $\mathrm{B} / 5$ & Disarticulation & Ovis aries & Atlas & Centrum & Ventral & Fine slices \\
\hline $\mathrm{B} / 5$ & Disarticulation & Ovis aries & Atlas & Centrum & Ventral & Deep slice \\
\hline $\mathrm{B} / 5$ & Disarticulation & Ovis aries & Atlas & Centrum & Dorsal & Fine slices \\
\hline $\mathrm{B} / 5$ & Disarticulation & Small bovid & Axis & Dens & Ventral & Fine slices \\
\hline
\end{tabular}


TABLE 13 Details of butchery evidence for carcass disarticulation on material recovered from phases 5 of Area B at Harlaa (cont.)

\begin{tabular}{|c|c|c|c|c|c|c|}
\hline Sample & Process & Taxon & Element & Portion & Location & Mark Type \\
\hline $\mathrm{B} / 5$ & Disarticulation & Small bovid & Lumbar & Centrum & Ventral & Chopped through \\
\hline $\mathrm{B} / 5$ & Disarticulation & Small bovid & Lumbar & Centrum & Ventral & Chopped through \\
\hline $\mathrm{B} / 5$ & Disarticulation & Small bovid & Lumbar & Centrum & Ventral & Chopped through \\
\hline $\mathrm{B} / 5$ & Disarticulation & Small bovid & Lumbar & Centrum & Ventral & Depp slice \\
\hline $\mathrm{B} / 5$ & Rib removal & Small bovid & Rib & Neck & Anterior & Fine slices \\
\hline $\mathrm{B} / 5$ & Throat Slicing & Small bovid & Hyoid & Stylohyoid & Posterior & Deep slice \\
\hline $\mathrm{B} / 5$ & Tongue Removal & Small bovid & Hyoid & Stylohyoid & Medial face & Fine slices \\
\hline $\mathrm{B} / 5$ & Disarticulation & Large bovid & Humerus & Distal & Trochlea & Chopped through \\
\hline $\mathrm{B} / 5$ & Disarticulation & Bos sp. & Humerus & Distal & Trochlea & Chopped through \\
\hline $\mathrm{B} / 5$ & Disarticulation & Bos sp. & Humerus & Distal & Trochlea & Chopped through \\
\hline $\mathrm{B} / 5$ & Disarticulation & Bos sp. & Radius & Proximal & Anterior & Chopped through \\
\hline $\mathrm{B} / 5$ & Disarticulation & Large bovid & Innominate & Illium & Wing & Deep slices \\
\hline $\mathrm{B} / 5$ & Disarticulation & Bos sp. & Innominate & Pubis & Acetabulum & Chopped through \\
\hline $\mathrm{B} / 5$ & Disarticulation & Bos sp. & Femur & Proximal & Capitus & Chopped through \\
\hline $\mathrm{B} / 5$ & Disarticulation & Large mammal & Tibia & Proximal & Tibial crest & Chopped through \\
\hline $\mathrm{B} / 5$ & Disarticulation & Bos sp. & Astragalus & Distal & Posterior & Fine slices \\
\hline $\mathrm{B} / 5$ & Disarticulation & Large bovid & Cervical & Centrum & Ventral & Chopped through \\
\hline $\mathrm{B} / 5$ & Disarticulation & Large bovid & Cervical & Centrum & Ventral & Chopped through \\
\hline $\mathrm{B} / 5$ & Disarticulation & Large bovid & Thoraxic & Centrum & Ventral & Chopped through \\
\hline $\mathrm{B} / 5$ & Disarticulation & Large bovid & Thoraxic & Centrum & Ventral & Chopped through \\
\hline $\mathrm{B} / 5$ & Disarticulation & Large bovid & Lumbar & Centrum & Ventral & Chopped through \\
\hline $\mathrm{B} / 5$ & Rib removal & Equus asinus & Rib & Neck & Anterior & Deep slices \\
\hline
\end{tabular}

with fine slices, chopping through the femoral capitus) which are not represented in the small sample of butchered bones recovered from either Ganda Harla or Harar.

\section{Identifying Islamic Butchery Practices and Diet in the Faunal Assemblages}

Halal butchery practices are specific only in the practice of slaughtering the animal, which is done via the severing of the throat to rapidly exsanguinate the animal (Francesca 2014; Kocturk 2002). This is achieved primarily through one of two approaches - a rapid and deep severing of the trachea, oesophagus and blood vessels with a knife from across the ventral surfaces of the throat (this being the primary technique) or the decapitation of the animal with a large implement (knife, cleaver, etc.) (Francesca 2014; Kocturk 2002). Of the 25 hyoid bones recovered from Harlaa (none were recovered from either Harar or Ganda Harla), eight have evidence of butchery. Of these, three bones bear cutmarks consistent with the slicing of the throat (one each from Area E, Area B, Phase 2, and Area B, Phase 5, Fig. 17). More specific guidance for the skinning or dismemberment of butchered animals is not given in the Qur'an or Hadith but can be reconstructed by comparison with other Islamic period faunal assemblages outside Ethiopia and the few proto-historic assemblages published from within Ethiopia. Analysis of butchery from late Aksumite and post-Aksumite phases of Bieta Guyorgis (Aksum) show some common traits with butchery evidence from Harlaa. The severing of the head and neck at the cranium-atlas junction using small slices can be seen at both sites. The severing of the elbow joint through fine slices to the proximal radius and the posterior margins of the distal humerus, as well as fine slices to the body of the hyoid bone from the removal of the tongue is also seen at both sites.

Several butchery practices evident in the Harlaa material are, however, not seen in the Bieta Guyorgis assemblage, but are found across multiple Islamic period sites in Arabia (e.g. Barbar), Anatolia (e.g. Gözlükule, Kaman-Kalehöuük), Mesopotamia (e.g. Tell Tuneinir), the Levant (e.g. Horbat 'Ofrat, Shallale, Tall al-Fukkar,), and Iberia (e.g. Alartos, Núcleo Arqueológico da Rua dos Correeiros) (Bangsgaard 2001, 2015; Estaca-Gómez et al 2019; Hongo 1997; Horwitz 2009; Loyet 1999; MorenoGarcia \& Gabriel 2001; Omar 2017). Generally, detailed discussions of butchery evidence are not common in 


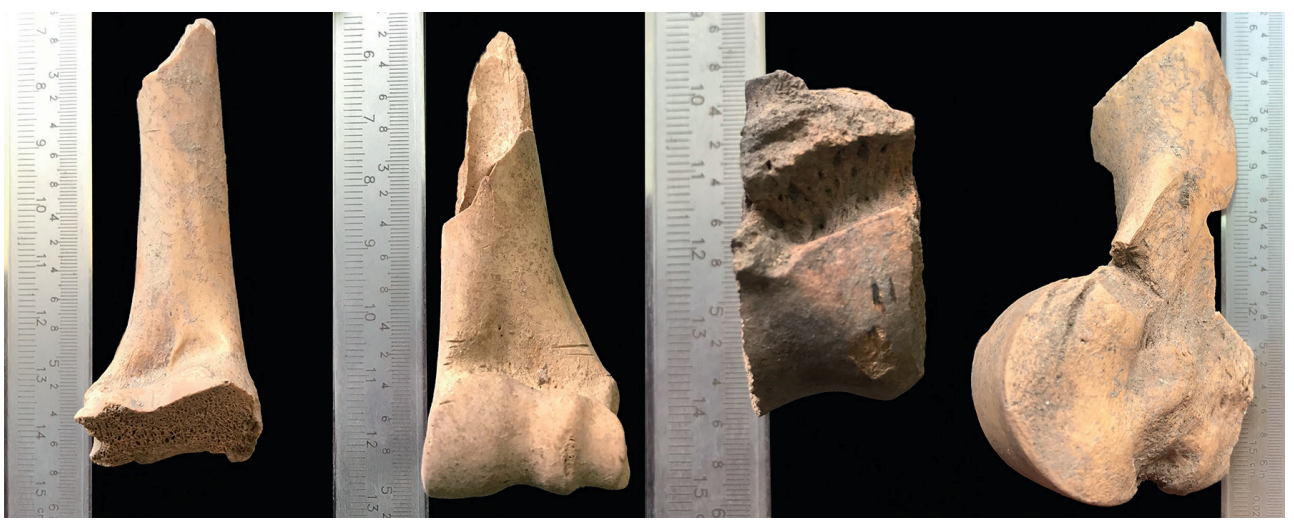

FIGURE 15 Examples of division of the carcass at the elbow by separating the distal humerus from the radius and ulna. Shown here are examples from (from left) Harlaa 2018 B(6), 2018 B(12), 2017 $\mathrm{B}(4)$ and $2019 \mathrm{E}(23)$.

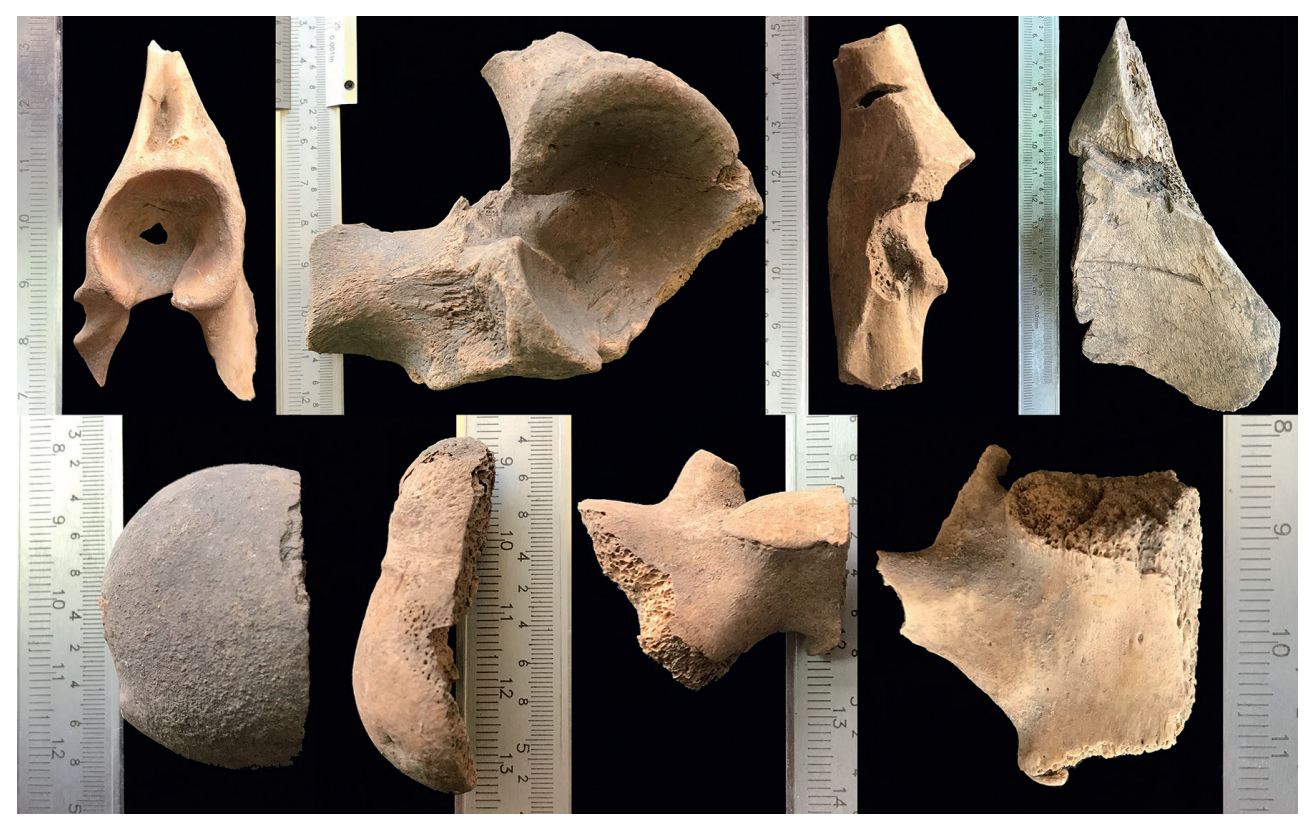

FIGURE 16 Examples of pelvic bones dismembered by chopping through the sacrum (lower right) and pubis (upper left), chopping free the femur through the head (lower left) and chopping the acetabulum free together with the femur (upper right). Shown here are examples from (from top left) Harlaa 2017 B(13), 2018 B(7), 2018 B(5), Harar 2014 SHA(A2c), Harlaa 2017 B(7), 2017 $\mathrm{B}(7), 2018 \mathrm{~B}(11)$ and $2018 \mathrm{~B}(6)$.

zooarchaeological literature from Islamic periods (cf. Insoll 1999: 95-99). Regardless, there are sufficient comparative examples to allow for the identification of particular key common practices. These involve butchery through the use of heavy knives, including the severing of the elbow joint by chopping through the distal trochlea of the humerus (Fig. 15), severing of the shoulder joint by chopping through the neck of the scapula or the humeral capitus (Fig. 14), the severing of the pelvic girdle either by chopping off the femoral capitus or by chopping free the acetabulum (Fig. 16), chopping through the distal tibia (Fig. 18), and lateral sectioning of the axial skeleton either in the removal of ribs (Fig. 19) or for the division of loins and tenderloins from the vertebral column (Fig. 20).

While it is difficult to conclusively determine that these forms of carcass dismemberment derive from cultural commonalities of the Islamic world given the infrequency of butchery discussions in zooarchaeological literature, the presence of so many common features across a range of sites which are all absent from Bieta Guyorgis suggests that the use of these butchery techniques are likely an identifiable part of Islamic cultural expansion into this region of Ethiopia. Although some of the butchery marks predate by several centuries the first evidence for Islam 


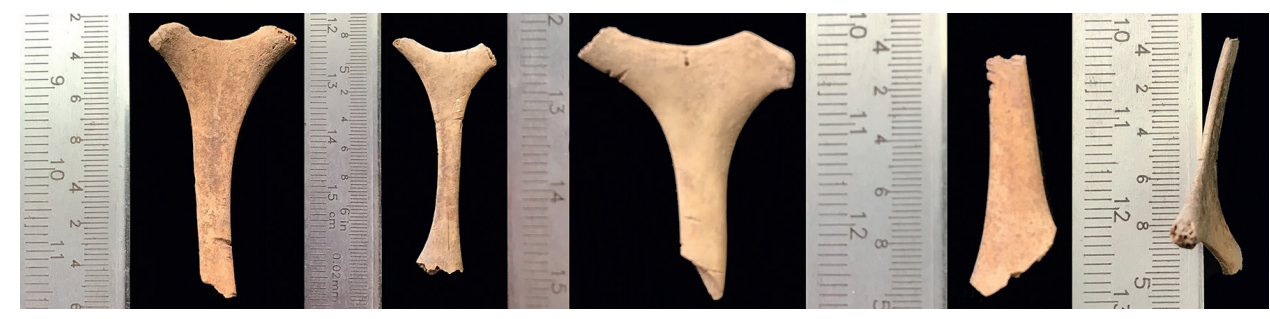

FIGURE 17 Examples of butchery marks found on hyoids from Harlaa. These are found on the medial surface and indicative of the removal of the tongue, and on the ventral margins of the hyoid indicating the slicing of the throat. Shown here are examples from (from left) Harlaa $2018 \mathrm{~B}(11), 2017 \mathrm{~B}(4), 2018 \mathrm{~B}(15), 2018 \mathrm{~B}(14)$ and $2017 \mathrm{~B}(4)$.

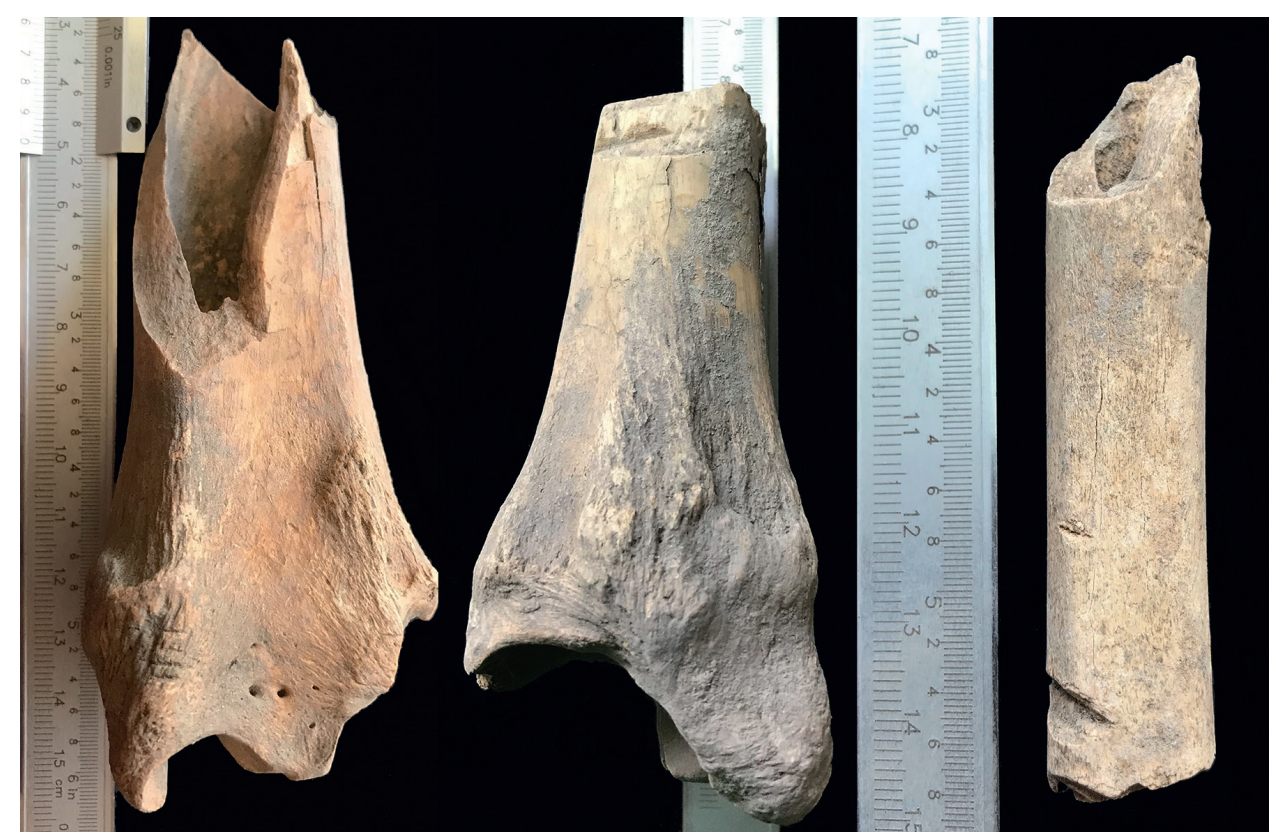

FIGURE 18 Examples of butchery of the lower hind limb at Harlaa. Removal of the tibia from the ankle joint by fine slices (left) and chopping through the distal tibia to segment out the leg joint (middle and right). Shown here are examples from (from left) Harlaa 2018 B(8), 2018 B(5) and $2017 \mathrm{~B}(20)$.

at Harlaa in the form of mosques or burials, the butchery techniques may have arisen initially with the movement of Muslim traders otherwise archaeologically unrecognised, and subsequently with the spread of Islamization to Harar, and, potentially, Ganda Harla, along with the adoption of new techniques with the spread of heavier butchery knives, or a combination of such factors.

It is noteworthy that Harlaa, Harar, and Ganda Harla share a predominance of ovicaprines, in particular goats, with various contemporary sites in the Islamic World (e.g. Bangsgaard 2015; Brown 2016; Hongo 1997; Horwitz 20o9; Loyet 1999; Studer et al. 2013; Taxel et al. 2017; von den Driesch \& Docker 2002). Similarly, in these comparative sites, goats were also mainly culled for their meat as older subadults while cattle were more commonly retained into adulthood, as were horses, donkeys and camels (Bangsgaard 2001, 2015; Hongo 1997; Horwitz 20o9; Loyet 1999).

Dietary prohibitions of varying degrees of severity also exist within different sects of Islam (Francesca 2014; Kocturk 2002; Rodinson 2012; Wheeler 2014). These include, for example, those specifically outlawed by the Qur'an - carrion, blood and pork - as well as those forbidden by Hadith and jurists within individual sects. These include cats, dogs, marine mammals, domestic equids (donkeys, horses or mules), predatory birds, carnivorous mammals, reptiles and most insects (Francesca 2014; Kocturk 2002; Wheeler 2014). Some animals are allowed within different sects (e.g. marine mammals for must Sunnī sects), thus variations in the presence or absence of prohibited animals may be indicative of Islamic dietary practices, as well sectarian traditions. However, 


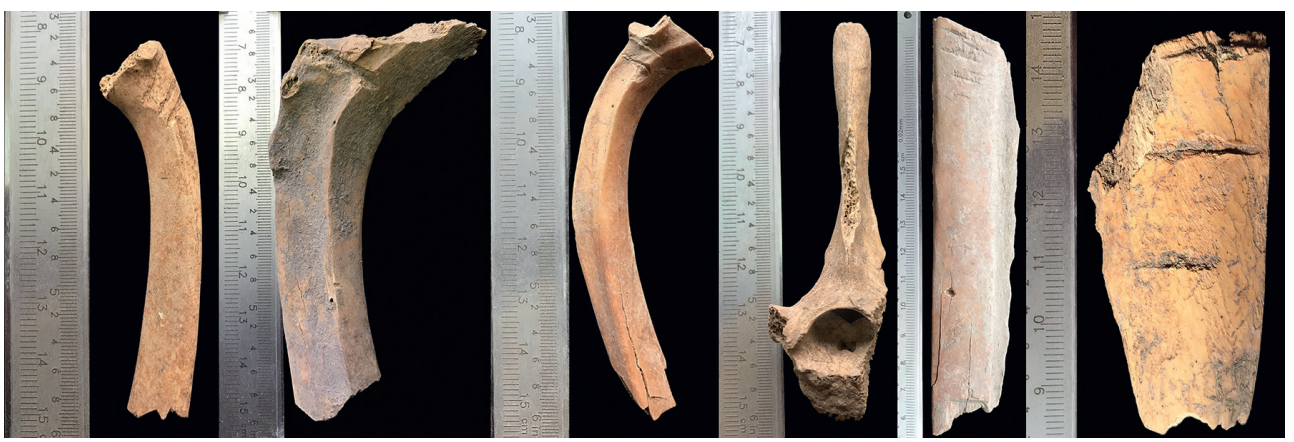

FIGURE 19 Examples of rib removal butchery traces from Harlaa. Shown here are examples from (from left) Harlaa $2017 \mathrm{~B}(20), 2018 \mathrm{~B}(7), 2017 \mathrm{~B}(20), 2019 \mathrm{E}(6), 2017 \mathrm{~B}(4)$ and $2019 \mathrm{E}(25)$.
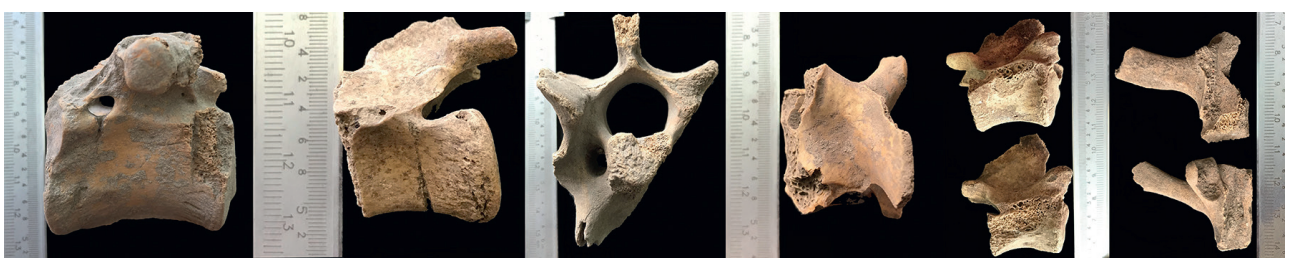

FIGURE 20 Examples of disarticulation sectioning of the vertebral column by different methods at Harlaa. Shown here are examples from (from left) Harlaa 2017 B(4), 2017 B(4), 2017 B(4), 2017 $\mathrm{B}(6), 2017 \mathrm{~B}(6), 2019 \mathrm{E}(7)$ and $2019 \mathrm{E}(7)$.

one complication with the use of faunal profiles for such ethnic or religious identification is that the observance of these rules is not necessarily universal across individuals, sites, or regions (Rodinson 2012). One example of this is the consumption of donkeys and tortoises. Consumption of domestic equids (donkeys, horses or mules) is prohibited under all schools of Islamic thought save for the Ḥanbalīs (and for horses, the Shāfi'îs) (Francesca 2014; Wheeler 2014). However, the remains of these animals (with indications of butchery, cooking, and consumption, especially of donkeys) are common across many sites of Islamic periods in both north Africa and south-west Asia (e.g. Bangsgaard 2015; Chaix \& Studer 2001; Estaca-Gómez et al. 2019; Loyet 2004; Marom 2019; MacKinnon 2017; von den Driesch \& Docker 2002), as well as at Harlaa, Harar and Ganda Harla. This presence of donkey might be taken as indicative of Sunnī rather than Shi'a sects (Francesca 2014; Wheeler 2014), were it not for an additional complicating factor - the presence of suids.

The consumption of pigs is universally outlawed across Islamic traditions (Francesca 2014; Kocturk 2002; Wheeler 2014). However, pig remains are also systematically present across a great many sites of Islamic periods in north Africa, the Levant, Mesopotamia, Arabia and Anatolia, albeit at very low levels (e.g. Bangsgaard 2015; Brown 2016; Bouchnick 2018; Chaix \& Studer 2001; Estaca-Gómez et al. 2019; García-Rivero et al. 2018; Hongo 1997; Horwitz 2009; Loyet 1999, 2004; MacKinnon 2017; Studer et al. 2013; Taxel et al 2017; von den Driesch \& Docker 2002). While there is no specific evidence for domestic pigs at Harlaa, Harar, or Ganda Harla, both Harlaa and Ganda Harla have evidence of suids (wild boar and bushpig). Suids are, in fact, more common at Harlaa and Ganda Harla than at Aksumite or post-Aksumite contexts from (Christian) Bieta Guyorgis and Mezber (Cain 2000; Chaix 2013; Woldekiros \& D'Andrea 2017), suggesting that Islamic dietary laws may not have been strictly observed at Harlaa or Ganda Harla, or that there was a non-Muslim population component in these sites, which is also feasible.

\section{Harlaa, Harar, and Ganda Harla in Comparative Regional Context}

The faunal assemblages from Harlaa, Harar and Ganda Harla provide a window into animal economies in eastern Ethiopia during the 7 th to 17 th centuries AD. Given the scarcity of faunal studies done in the Horn of Africa from these periods there are few sites against which to compare the samples. At Mifsas Bahri for example, a late Aksumite site in southern Tigray dated to between c. 550700 , the recovery of $34.6 \mathrm{~kg}$ of animal bones is referred to (Yule 2017: 76), but no further information on this material is provided. Similarly, excavations at Mezber have produced isotopic studies on the recovered remains of both humans and (studied) animals, although after more than 
a decade only the domestic chicken remains have been published (Woldekiros \& D'Andrea 2017).

However, a wider regional comparison can be made between Harlaa, Harar and Ganda Harla and some other sites of late- and post-Aksumite northern Ethiopia (c. 6th to 9 th/1oth centuries AD). From comparison with multiple settlement contexts excavated at Bieta Guyorgis it can be seen that cattle were the predominant domesticate in late- and post-Aksumite periods, and sheep dominated slightly over goats (Cain 200o; Chaix 2013). Both of these patterns are in contrast to the findings from Harlaa. Cattle were the most common domesticate at both Harar and Ganda Harla, although the ovicaprines represented at these sites indicate a predominance of goats in common with Harlaa and unlike samples from Bieta Guyorgis. While fish remains were recovered from both Bieta Guyorgis (Cain 2000) and Harlaa, the fish species at the former are all local freshwater species, while those from Harlaa represented imported maritime species. Chickens are found on all sites, although the guinea fowl (Numida meleagris) is absent from Aksumite sites (Cain 2000; Chaix 2013; Woldekiros \& D'Andrea 2017) and is only represented in the earlier occupational phases at Harlaa (up to the late 13 th century $\mathrm{AD}$ ).

Some differences in the management of domestic animals can also be seen. In both regions, cattle were predominately culled as adults, although the proportion of cattle culled prior to adulthood is slightly higher from Bieta Guyorgis samples (Cain 2000; Chaix 2013). From analyses of post-cranial fusion only c. $60-80 \%$ of cattle can be seen to survive into adulthood at Bieta Guyorgis sites compared with $80-100 \%$ of cattle surviving into adulthood at Harlaa, Harar and Ganda Harla. Sheep and goats from Bieta Guyorgis indicate a high culling of infant and juvenile individuals and young subadults (under two years of age) in contrast with the pattern of high culling of older subadult animals seen at Harlaa (Chaix 2013). This suggests that the management practices were different, although the lack of separated age profiles for sheep and goats from the Aksumite sites makes it difficult to confirm this.

\section{Conclusions}

The faunal assemblages from Harlaa, Harar, and Ganda Harla have provided significant information on animal economies and religious identity in medieval Ethiopia, and for the first time from an Islamic archaeological context. The appearance of a similar range of butchery techniques suggests that these were linked with the appearance of
Muslim traders at Harlaa, and the subsequent spread of Islam to Harar and Ganda Harla. Intriguingly, at Harlaa, Islamic butchery techniques predate other markers of Islam such as mosques or burials by at least four centuries, suggesting that some Muslims might have been present much earlier, but are otherwise materially intangible. The presence of wild pig at Harlaa and Ganda Harla, tortoise rarely at Harlaa, but more commonly at Harar and Ganda Harla, and donkey at all three sites indicates dietary eclecticism, and at Harlaa and Ganda Harla the non-observance of Islamic dietary rules and/or the presence of mixed communities. At Harar, the absence of pig remains infers greater Islamic orthodoxy which would concur with its status as a city of Muslim scholarship and pilgrimage (Insoll \& Zekaria 2019).

Social inferences may also be made. The absence of cross-site differences in animal body portions consumed at Harlaa areas B, E, and F, or at Harar and Ganda Harla suggests wealth or status may not have been a factor in access to meat. This correlates to a certain extent with distribution patterns of artifacts such as imported glazed pottery, beads, and shells at Harlaa, which do not show significant disparities across the site, but any such wealth correlations cannot be determined at Harar and Ganda Harlaa where these categories of prestige artifacts were generally absent (Insoll 2017). Similarities across the three sites were also evident in, for example, some of the species present, and in the hunting of small bovids.

The data also indicates differences among the sites, particularly between Harlaa, and Harar and Ganda Harla. For domesticates, goat dominates at Harlaa, and cattle at the latter two sites. All bird bones are absent from Ganda Harla and guinea fowl is only present at Harlaa, and only in the 11th-13th centuries. Imported, probably processed, marine fish are found at Harlaa, with no fish remains occurring at the other sites. Aspects of animal management strategies also appear to differ. The increased slaughter of sub-adult goats at Harlaa compared to Harar and Ganda Harla implies a more cautious approach at the latter sites where there was an emphasis on the increase or perpetuation of livestock numbers. Cattle appear to have only been used for traction at Harlaa. The patterns which are emerging from these faunal assemblages indicate the development of animal economies and dietary identities that are both connected with the wider Islamic world and rooted in the local environment. To explore these more fully it is imperative that comparable zooarchaeological analyses are undertaken at other late Aksumite, medieval, and Islamic sites in Ethiopia and elsewhere in the Horn of Africa. 


\section{Acknowledgements}

Timothy Insoll and Jane Gaastra are grateful to the ERC for funding this research under the European Union's Horizon 2020 research and innovation programme (Advanced Grant agreement No 694254). They are also grateful to the Authority for Research and Conservation of Cultural Heritage in Addis Ababa, the regional Bureaus in Harar and Dire Dawa, and the Kebele in Ganda Biyo (Harlaa), for giving permission for the research to proceed, and to their colleagues Dejene Dandema, Misganaw Gebremikael, Nadia Khalaf, Rachel MacLean, Hannah Parsons, and Nicholas Tait for assistance in the field.

\section{Supplementary Material}

Supplementary material is available online at: https://doi.org/10.6o84/m9.figshare.1215279o

\section{References}

Ahmed, A.M. 1990. A survey of the Harar Djugel (wall) and its gates. Journal of Ethiopian Studies 23, 321-34.

Bangsgaard, P. 2001. Animal bones from the Barbar well. In: Frifelt, K. (ed.), Islamic Remains in Bahrain. Aarhus University Press, Aarhus, pp. 183-20o.

Bangsgaard, P. 2015. Animal bones. In: Strange, J. (ed.), Tallal-Fukhar, Result from the Excavations in 1990-93 and 2002, vol. I Text. The Danish Institute in Damascus, Copenhagen, pp. 378-397.

Bartosiewicz, L. 2008. Bone structure and function in draft cattle. In: Grupe, G., McGlynn, G. \& Peters, J. (eds.), Limping Together through the Ages:Joint Afflictions and Bone Infections. Marie Leidorf GmbH, Rahden, pp. 153-164.

Bartosiewicz, L., Van Neer, W. \& Lentacker, A. 1997. Draught Cattle: Their Osteological Identification and History. Annalen Koninklijk Museum voor Midden-Afrika, Zoologische Wetenschappen, Tervuren.

Bekele, A. \& Yalden, D.W. 2013. The Mammals of Ethiopia and Eritrea. Addis Ababa University Press, Addis Ababa.

Binford, L.W. 1981. Bones: Ancient Men and Modern Myths. Academic Press, New York.

Boessneck, J., Müller, H.H. \& Teichert, M. 1963. Osteologische Unterscheidungsmerkmale zwischen Schafe (Ovis aries Linné) und Ziege (Capra hircus Linné). Kühn Archiv 78, 1-129.

Bouchnick, R. 2018. Stocking or abandonment: wild boar remains deposited in an Early Islamic context (accumulation 2626) at Tel Hevron. Judea and Samaria Research Studies 27 (1), 59-75.
Brain, C.K. 1974. Some suggested procedures in the analysis of bone accumulations from southern African Quaternary sites. Annals of the Transvaal Museum 29, 1-8.

Brown, R.M. 2016. Faunal distributions from the southern highlands of Transjordan: regional and historical perspectives on the representations and roles of animals in the Middle Islamic Period. In: McPhillips, S. \& Wordsworth, P.D. (eds.), Landscapes of the Islamic World: Archaeology, History, and Ethnography. University of Pennsylvania Press, Philadelphia, pp. 71-93.

Cain, C.R. 200o. Animals at Axum: Initial Zooarchaeological Research in the Later Prehistory of the Northern Ethiopian Highlands. Unpublished PhD thesis, Washington University of St. Louis.

Chaix, L. 2013. The fauna from the UNO/BU excavations at Bieta Guyorgis (Aksum) in Tigray, northern Ethiopia: campaigns 1995-2003; Pre-Aksumite, 700-400 BC to Late Aksumite, AD 800-1200. Journal of African Archaeology 2, 211-241.

Chaix, L., \& Studer, J. 2001. Le faune de quelques sites Islamiques de la Moyenne Vallée de l'Euphrate (fin VIIe-XIVe siècle). (In: Berthier, S., Chaix, L., Studer, J., D’Hont, O., Gyselen, R., \& Samuel, D. (eds.), Peuplement Rural et Aménagements Hydroagricoles dans la Moyenne Vallée de l'Euphrate Fin $V I I^{e}-X I X^{e}$ Siècle. Institut Français d'Études Arabes de Damas, Damascus, pp. 302-340.

Chekroun, A., Fauvelle-Aymar, F-X., Hirsch, B., Ayenachew, D., Zeleke, H., Onezime, O., \& Shewangizaw, A. 2011. 'Les Harla: Archéologie de Mémoire des Géants d'Ethiopie'. In: Fauvelle-Aymar, F.-X. \& Hirsch, B. (eds.), Espaces Musulmans de la Corne de l'Afrique au Moyen Âge. De Boccard, Paris, pp. 75-102.

CIRPS \& Harari People National Regional State. 2003. Cultural Heritage of Harar. Mosques, Islamic Holy Graves, and Traditional Harari Houses. A Comprehensive Map. University of Rome, Rome.

Estaca-Gómez, V., Malalana-Ureña, A., Yravedra, J., Matás, G.J.L. \& de Pablos, J.M. 2019. Economic implications of livestock management strategies in the center of the Iberian Peninsula, Tagus Basin, and Mancha Alta region between the VIII and XI centuries AD. Archaeological and Anthropological Sciences 11 (4), 1289-1305.

Francesca, E. 2014. Dietary law. In: Fleet, K, G., Krämer, G., Matringe, D., Nawas, J. \& Rowson, E. (eds.), Encyclopedia of Islam Third Edition. Brill, Leiden.

Gaastra, J.S. 2016. The Quadratic Crown Height Method and bovidae: Ageing sheep (Ovis aries), goats (Capra hircus) and cattle (Bos taurus). Journal of Archaeological Science: Reports 10, 172-19o.

García-Rivero, D., Taylor, R., Pérez-Aguilar, L.G., Pérez-Jordá, G., García-Viñas, E., López-Sáez, J.A., Zurro, D., Peña-Chocarro, L. \& Bernáldez-Sánchez, E. 2018. Andalusi populations at La 
Dehesilla cave (Sierra de Cádiz, southern Iberia): an interdisciplinary approach to their rural economic systems. Journal of Islamic Archaeology 5 (2), 119-151.

González-Ruibal, A., Suárez, C.M., Manuel Sánchez-Elipe, M., Lesurc, J. \& Barrio, C.M. 2014. Late hunters of western Ethiopia: the sites of Ajilak (Gambela), c. AD 1000-1200. Azania: Archaeological Research in Africa 49 (1), 64-101.

Grant, A. 1982. The use of tooth wear as a guide to the age of domestic ungulates. In: B. Wilson, C. Grigson and S. Payne (eds.), Ageing and Sexing Animal Bones from Archaeological Sites. BAR British Series 109. British Archaeological Reports, Oxford, pp. 91-108.

Grigson, C. 1982. Sex and Age Determination of Some Bones and Teeth of Domestic Cattle: A Review of the Literature. In: Wilson, B., Grigson, C. \& Payne, S. (eds.), Ageing and Sexing Animal Bones from Archaeological Sites. BAR British Series 109. British Archaeological Reports, Oxford, pp. 7-24.

Halstead, P. 1985. A study of mandibular teeth from RomanoBritish contexts at Maxey. In: Pryor, F., French, C., Crowther, D., Gurney, D., Simpson, G. \& Taylor, M. (eds.), The Fenland Project: Archaeology and Environment in the Lower Welland Valley, Volume 1. East Anglican Archaeology Report No. 27. The Fenland Committee (Cambridgeshire Archaeological Committee), Cambridge, pp. 219-224.

Hongo, H. 1997. Patterns of animal husbandry, environment and ethnicity in Central Anatolia in the Ottoman Empire Period: faunal remains from Islamic layers at Kaman-Kalehöuük. Japan Review 8, 275-307.

Horton, M. 1994. East Africa. In: Frishman, M. \& Khan, H.-U. (eds.), The Mosque. Thames and Hudson, London, pp.194-207.

Horwitz, L.K. 2009. Roman through Ottoman period fauna from H. Shallale. In: Dar, S. (ed.), Shallale - Ancient City of the Carmel. British Archaeological Reports International Series 1987. Archaeopress, Oxford, pp. 321-340.

Insoll, T. in press. The Islamic archaeology of Ethiopia and the Horn of Africa. In: Walker, B., Insoll, T., \& Fenwick, C. (eds.), The Oxford Handbook of Islamic Archaeology. Oxford: Oxford University Press.

Insoll, T. 2017. First footsteps in the archaeology of Harar.Journal of Islamic Archaeology 4, 189-215.

Insoll, T. 1999. The Archaeology of Islam. Blackwell, Oxford.

Insoll, T. Tesfaye, H., \& Mahmoud, M. S. 2014. Archaeological survey and test excavations, Harari Regional State, Ethiopia, July-August 2014: a preliminary fieldwork report. Nyame Akuma, 82, 100-109.

Insoll, T., \& Zekaria, A. 2019. The mosques of Harar: an archaeological and historical study. Journal of Islamic Archaeology 6 , 81-107.

Jones, G.G. \& Sadler, P. 2012a. Age at death in cattle: methods, older cattle and known-age reference material. Environmental Archaeology 17 (1), 11-28.
Jones, G.G. \& Sadler, P. 2012b. A review of published sources for age at death in cattle. Environmental Archaeology 17 (1), 1-10.

Joussaume, H., \& Joussaume, R. 1972. Anciennes Villes dans le Tchercher. Annales d'Éthiopie 9, 21-44.

Khalaf, N., \& Insoll, T. 2019. Monitoring Islamic archaeological landscapes in Ethiopia using open source satellite imagery. Journal of Field Archaeology 44 (6), 1-19.

Kocturk, T.O. 2002. Food rules in the Koran. Scandinavian Journal of Nutrition 46 (3), 137-139.

Lesur, J., Vigne, J.-D. \& Gutherz, X. 2007. Exploitation of wild mammals in south-west Ethiopia during the Holocene (400o BC-500 AD): the finds from Moche Borago shelter (Wolayta). Environmental Archaeology 12 (2), 139-159.

Lin, M., Miracle, P. \& Barker, G. 2016. Towards the identification of the exploitation of cattle labour from distal metapodials. Journal of Archaeological Science 66, 44-56.

Loyet, M.A. 1999. Small ungulate butchery in the Islamic period (A.D. 632-126o) at Tell Tuneinir, Syria.Journal of Near Eastern Studies 58 (1), 33-45. https://doi.org/10.1086/468670

Loyet, M.A. 2004. Food, fuel and raw material: faunal remains from Al-Basra. In: Benco, N.L. (ed.), Anatomy of a Medieval Islamic Town: Al-Basra, Morocco. British Archaeological Reports International Series 1234. Archaeopress, Oxford, pp. 21-29.

Lyman, R.L. 2008. Quantitative Paleozoology. Cambridge University Press, Cambridge.

Marom, N. 2019. Animal bones from Iron Age and Mamlukperiod contexts in Horbat 'Ofrat. 'Atiqot 95, 129-144.

MacKinnon, M. 2017 Animals, acculturation and colonization in ancient and Islamic North Africa. In: Albarella, U. (ed.), The Oxford Handbook of Zooarchaeology. Oxford University Press, Oxford, pp. 466-478.

Moreno-Garcia, M. \& Gabriel, S. 2001. Faunal remains from 3 Islamic contexts at Núcleo Arqueológico da Rua dos Correeiros, Lisbon. Trabalhos do Centro de Investigação em Paleoecologia Humana e Arqueociências 20, 1-30.

Nilssen, P.J. 200o. An Actualistic Butchery Study in South Africa and its Implications for Reconstructing Hominid Strategies of Carcass Acquisition and Butchery in the Upper Pleistocene and Plio-Pleistocene. Unpublished PhD thesis, University of Cape Town.

Olsen, S.J. 196o. Post-Cranial Skeletal Characters of Bison and Bos. Peabody Museum, Cambridge.

Omar, L. 2017. Approaching Medieval cuisine: employing zooarchaeological methods on Anatolian faunal assemblages. In: Vroom, J., Waksman, Y., \& van Oosten, R. (eds.), Medieval MasterChef: Medieval and Post-Medieval Mediterranean Archaeology. Brepols, Turnhout, pp. 95-115.

Patassini, D. 2006. A Museum for Haräla. IUAV 41: 6-8.

Payne, S., 1973. Kill-off patterns in sheep and goats: the mandibles from Aşvan Kale. Anatolian Studies 23, 281-303. 
Prummel, W. 1987a. Atlas for the identification of foetal skeletal elements of cattle, horse, sheep and pig, Part I. Archaeozoologica 1 (1), 23-30.

Prummel, W. 1987 b. Atlas for the identification of foetal skeletal elements of cattle, horse, sheep and pig, Part II. Archaeozoologica 1 (2), 11-41.

Rodinson, M. 2012. Ghidha. In: Bearman, P., Bianquis, Th., Bosworth, C.E., van Donzel, E. \& Heinrichs, W.P. (eds.), The Encyclopaedia of Islam, Second Edition. Brill, Leiden.

Seetah, K. 2007. Butchery as an Analytical Tool: a Comparative Study of the Romano-British and Medieval Periods. Unpublished PhD thesis, University of Cambridge.

Studer, J., Genequand, D. \& Rousset, M-O. 2013. Environmental influence on animal exploitation and meat consumption during the Early Islamic Period in Syria: a case study from Qasr al-Hayr al-Sharqi and Al-Hadir. In: De Cupere, B., Linseele, V. \& Hamilton-Dyer, S. (eds.), Archaeozoology of the Near East X. Peeters, Leuven, pp. 265-282.

Taxel, I., Glick, A. \& Pines, M. 2017. Majdal Yābā: more insights on the site in Medieval and Late Ottoman to Mandatory times. Journal of Islamic Archaeology 4 (1), 49-86.

Tesfaye, H., Solomon, T. \& Abdu, Y. 2013. A Preliminary Archaeological Survey at Gende-Harla Site of Harari Region. Unpublished report. Addis Ababa: ARccH.

von den Driesch, A. 1976. A Guide to the Measurement of Animal Bones from Archaeological Sites. Peabody Museum, Cambridge.

von den Driesch, A. \& Docker, A. 2002. Animal exploitation in Medieval Siraf, Iran, based on the faunal remains from the excavations at the Great Mosque (seasons 1966-1973). Bonner Zoologische Beiträge 50 (3), 227-247.

Walker, R. 1986. A Guide to the Post-Cranial Bones of East African Animals. Hylochoerus Press, Norwich.

Wheeler, B. 2014. Animals, in law. In: Fleet, K., Krämer, G., Matringe, D., Nawas, J. \& Rowson, E. (eds), Encyclopedia of Islam, Third Edition. Brill, Leiden.

Woldekiros, H.S. \&cand D'Andrea, A.C. 2017. Early evidence for domestic chickens (Gallus gallus domesticus) in the Horn of Africa. International Journal of Osteoarchaeology 27, 329-341.

Yule, P. 2017. The Small Finds Mifsas Bahri Site oo1. In: Gaudiello, M., \& Yule, P. (eds.), Mifsas Ba hrri: A Late Aksumite Frontier Community in the Mountains of Southern Tigray. British Archaeological Reports International Series 2839. Archaeopress, Oxford, pp. 76-79.

Zeder, M.A. 2006. Reconciling rates of long bone fusion and tooth eruption and wear in sheep (Ovis aries) and goat (Capra hircus). In: Ruscillo, D. (ed.), Recent Advances in Ageing and Sexing Animal Bones. Oxbow, Oxford, pp. 87-118.

Zeder, M.A. \& Lapham, H.A. 2010. Assessing the reliability of criteria used to identify postcranial bones in sheep, Ovis, and goats, Capra. Journal of Archaeological Science 35 (11), 2887-2905.

Zeder, M.A. \& Pilaar, S.E. 2010. Assessing the reliability of criteria used to identify mandibles and mandibular teeth in sheep, Ovis, and goats, Capra. Journal of Archaeological Science 37 (2), 225-242. 